\title{
$\beta$-catenin has an ancestral role in cell fate specification but not cell adhesion
}

\author{
Authors: Miguel Salinas-Saavedra ${ }^{1 *}$, Athula H. Wikramanayake ${ }^{2 *}$, and Mark Q Martindale ${ }^{1 *}$.
}

\section{Affiliations:}

${ }^{1}$ The Whitney Laboratory for Marine Bioscience, and the Department of Biology, University of Florida, 9505 N, Ocean Shore Blvd, St. Augustine, FL 32080-8610, USA.

${ }^{2}$ Department of Biology, University of Miami, Coral Gables, FL 33124, USA.

*Correspondence to:

MS-S: mssaavedra@whitney.ufl.edu; mssaavedra@gmail.com

AHW: athula@miami.edu

MQM: mqmartin@whitney.ufl.edu

\section{Abstract:}

The B-catenin protein has two major known functions in animal cells. It keeps epithelial tissue homeostasis by its connection with Adherens Junctions (AJ), and it serves as a transcriptional cofactor along with Lef/Tcf to enter the nucleus and regulate target genes of the Wnt/ß-catenin (cWnt) signaling pathway. To assess the ancestral role of $\beta$-catenin during development we examined its distribution and function in the ctenophore Mnemiopsis leidyi (one of the earliest branching animal phyla) by using ctenophore-specific antibodies and mRNA injection. We found that $ß$-catenin protein never localizes to cell-cell contacts during embryogenesis as it does in other metazoans, most likely because ctenophore-cadherins do not have the cytoplasmic domain required for interaction with the catenin proteins. Downregulation of zygotic $M l ß$-catenin signaling led to the loss of endodermal and mesodermal tissues indicating that nuclear $\beta$-catenin may have a deep role in germ-layer evolution. Our results indicate that the ancestral role for $\beta$ catenin was in the cell-fate specification and not in cell adhesion and also further emphasizes the critical role of this protein in the evolution of tissue layers in metazoans. 


\section{BACKGROUND}

Animal evolutionary history has generated an intriguing diversity of body plans. Changes in developmental programs within and between animal lineages are required to generate this diversity. Within these changes, different modes of gastrulation are observable between major animal groups. For example, the site of gastrulation is specified at the vegetal pole in bilaterians, while in cnidarians and ctenophores it is specified at the animal pole (Figure 1) (1-3). Decades of research suggests that this shift of the site of gastrulation in animal evolution may be related to major body plan transitions due to its early role in germ cell-layer specification and embryonic body patterning $(1-4)$.

Interestingly, the translocation of $ß$-catenin from the cytoplasm into the nucleus of blastomeres specifies the site of gastrulation in embryos of both bilaterian and cnidarian species (4-17). Thus, to understand how the subcellular localization of this protein is regulated has become a major topic of study in developmental biology research $(3,8,18-26)$. B-catenin protein displays three different dominant cellular localizations: cytosolic, cortically attached to Adherens Junctions (AJs), and acting as a transcriptional co-factor inside of the nucleus $(19,20)$. Each of these localizations is regulated by specific molecular pathways whose components interact together as modules that organize cells in specific developmental contexts.

In most cells $\beta$-catenin cytoplasmic levels are tightly regulated by its interaction with a destruction complex (GSK3ß/Axin/APC/CK1) where it is sequentially phosphorylated by CK1 and GSK3ß, which targets it for degradation in the proteasome $(19,25)$. On the other hand, when a Wnt ligand is present, cortical Dishevelled (Dvl) inhibits the action of GSK3ß and releases $\beta$ catenin from its destruction complex. Free available cytosolic $\beta$-catenin is either sequestered by apically polarized E-cadherin to the cell cortex or translocated to the nucleus. In the cell cortex, ß-catenin binds to the cytoplasmic domain of E-cadherin and alpha-catenin that forms the AJ belt complex required to connect these apical junctions to the cytoskeleton $(19,25)$. Nuclear $\beta-$ catenin has to interact with transcriptional factors such as LEF/TCF before inducing the expression of a variety of target genes. During bilaterian development cWnt signaling induces genes (e.g. snail, brachyury, twist) associated with the gene regulatory networks that determine endomesodermal cell fate $(8,19,25,27)$. 
Recent work has indicated that the cWnt pathway was involved in endomesoderm specification in the last common ancestor to bilaterians and cnidarians $(19,20)$. Since $\beta$-catenin also plays a critical role in cell adhesion, an outstanding question is if the ancestral role of this protein was in cell adhesion or in cell fate specification. Ctenophores provide an important model system to investigate this question. Ctenophores diverged prior to the cnidarian-bilaterian ancestor during animal evolution and the phylogenetic position of ctenophores may represent the earliest-branching extant animal clade (28-31). Ctenophores possess definitive muscle and mesenchymal cells in their mesoglea that are derived from endomesodermal precursors that cnidarians lack, thus, ctenophores provide a powerful opportunity to study the evolution of molecular mechanisms that may control $\beta$-catenin localization and germ layer specification.

Despite the fact that genomic studies have shown the conservation of structural components of the $\beta$-catenin protein in ctenophores (32-34), some upstream and downstream genes associated with its proper subcellular localization do not seem to be present in their genomes $(30,33,34)$. For example, ctenophores do not appear to have the genes encoding for most cell-cell adhesion systems $(34,35)$, Wnt/planar cell polarity (PCP), and bilaterianmesoderm $(30,33)$. Ctenophore cadherin does not have the cytoplasmic domains that bind to catenins $(30,34)$, and therefore, AJs cannot become functional in epithelial cells in the same way as it does in bilaterians and cnidarians. Moreover, ß-catenin zygotic expression starts after gastrulation is completed (33). Hence, the sequestration, degradation, and subcellular localization of $\beta$-catenin could be quite different to what has been described for bilaterians and cnidarians. All this together brings the question of what the ancestral role of $\beta$-catenin might be in animal development and whether or not $\beta$-catenin is involved in embryonic patterning as in other studied animals. Interestingly, a ß-catenin homolog has been described in the slime mold Dictyostelium discoidin (36) and has been implicated in the formation of the multicellular "slug" stage of their life cycle, suggesting that $ß$-catenin protein domains might have been involved in cell adhesion well before animals existed. Here, we developed a specific antibody (Figure S1; supplementary material) against Mnemiopsis leidyi ß-catenin (Mßß-catenin) and analyzed its subcellular localization during the ctenophore $M$. leidyi embryogenesis. We have made fusion protein where $M l ß$-catenin was fused to a fluorescent protein and expressed them in embryos by microinjection 
of mRNA so that we can visualize their localization in live animals. In addition, we tested the function of ß-catenin by the downregulation of its signaling. Regardless of the differences in the mechanism that regulate $\beta$-catenin localization between ctenophores and (cnidaria+bilateria), we find no evidence that $\beta$-catenin is involved in cell adhesion and our data suggest an ancestral role of nuclear $M l ß$-catenin in tissue specification at the site of gastrulation during early M. leidyi gastrulation.

\section{RESULTS}

\section{M. leidyi $\mathbf{\beta}$-catenin localizes in the nuclei of prospective endodermal cells}

The ctenophore M. leidyi develops by a highly stereotyped and synchronous cleavage program (Figure 1B; detailed in supplementary material) $(37,38)$. The eggs of M. leidyi are polarized along the animal-vegetal axis and $(39,40)$ the first cleavage furrow is observable at the animal pole 45-60 minutes post fertilization at room temperature $\left(25^{\circ} \mathrm{C}\right)$. Subsequent rounds of division occur every 10 to $20 \mathrm{~min}$. Nuclear $M l \beta$-catenin protein (nMlß-catenin) is observable in the egg and in every blastomere until the 16-cell stage (Figures 2A, 2B, and S2). At this stage, $\mathrm{n} M l ß$-catenin is present in every cell except for the middle vegetal micromeres (' $\mathrm{m}_{1}$ ' (38): prospective apical organ, tentacles epithelium, and nerve tissues) where $M l ß$-catenin remains cytosolic (Figure 2A). Gastrulation in M. leidyi embryos takes place at the animal pole around 3 hpf. The presumptive ectodermal micromeres derived from the vegetal pole expand and migrate towards the animal pole covering the endomesodermal macromeres by epiboly. During these stages $\mathrm{n} M l \beta$-catenin is present in the nuclei of animal macromeres that will develop into the endomesoderm (Figure S3A). While cells undergoing epiboly advance towards animal cells, cytosolic $M l ß$-catenin becomes transiently nuclearized in some micromeres in closer contact with animal macromeres that will later become pharyngeal cell precursors ( $3 \mathrm{hpf}$; Figure S3A). Therefore, $M l ß$-catenin nuclearization is regulated by maternally loaded components and may have cell-fate specification roles before the zygotic expression of this protein.

During the formation of the prospective 'mesoderm' (4-4.5 hpf), Mlß-catenin localizes to the nuclei of prospective endodermal cells but remains cytosolic in the ectoderm and prospective 'mesoderm' (Figure 3A and S3A). Interestingly, at the vegetal pole, $\mathrm{n} M l \beta$-catenin is transiently present in a subset of cells parallel to the tentacular plane (4 hpf; Figure $3 \mathrm{~A})$. However, this 
vegetal nuclearization disappears by the end of the next round of cell division where $\mathrm{n} M l ß-$ catenin is only observable in the endodermal cells located between the invaginated (prospective) 'mesoderm' and outer ectoderm (Figure 3A). Importantly, we never observed cortical localization of $M l ß$-catenin at the level of cell-cell junctions during any of these stages. These observations together suggest that the Wnt/ß-catenin canonical pathway gets activated first at the animal pole and at the site of gastrulation regardless of the lack of zygotic Wnt and B-catenin gene expression in those cells at those stages (as assayed by whole mount in situ hybridization) (33).

To confirm our observations, we cloned Mlß-catenin (from 8-cell stage embryos) and developed an mRNA construct encoding for $M l ß$-catenin fused to mScarlet $(M l \beta-$ catenin::mScarlet) that was injected into zygotes, and the in vivo localization of the protein was recorded for the first time in M. leidyi embryos (Figure S4). The translated $M l ß-$ catenin::mScarlet was observed after 4 to 5 hours post injection, and therefore, it was impossible to observe this protein during early cleavage stages. During gastrulation, Mlß-catenin::mScarlet was distributed uniformly in the cytosol and it was observed in the nuclei of oral macromeres (Figure S4) confirming our immunohistochemical observations (Figure 3 and S3).

\section{M. leidyi B-catenin transiently localizes in the nuclei of every cell during and after gastrulation}

At later stages of development, $M l \beta$-catenin remains cytosolic with no cortical localization observed (i.e. as would be expected if it were associated with cell-cell junctions) (Figure S3). During mid-gastrulation (5 hpf), when migrating 'mesodermal' cells are in direct contact with the ectodermal cells at the vegetal pole, $\mathrm{n} M l ß$-catenin is observable in all cells at apparently different concentrations (Figure 3A and Movie S1). At this stage, $\mathrm{n} M l \beta$-catenin is highly concentrated in endodermal and 'mesodermal' cells, as well as, in some ectodermal cells: four pairs of cell rows in each embryonic quadrant and in a 'ring' of cells around the vegetal pole. Between 5-6 hpf, $M l ß-c a t e n i n$ remains cytosolic in all cells (Figure S3B) and 'mesodermal' cells start to migrate underneath the overlying vegetal ectoderm.

At $6 \mathrm{hpf}$ (Figure 3B), nMlß-catenin is only observable in endodermal and 'mesodermal' cells until $8 \mathrm{hpf}$ (Figure 3B). Intriguingly, between 8 and $9 \mathrm{hpf}, \mathrm{n} M l \beta$-catenin is observable in all cells 
of the embryo at apparently different concentrations in ectodermal cells (Figure 3B). At this stage, $\mathrm{n} M l ß$-catenin is highly concentrated in endodermal and 'mesodermal' derivatives, as well as, in some ectodermal cells: pharynx, comb plates, and tentacle ectodermal-sheath. After 9 hpf, $\mathrm{n} M l ß$-catenin is only observable in all endoderm and mesodermally derived tissues and in the ectodermally derived pharynx, comb plates, and apical organ. In addition, we observed nMlßcatenin in two discrete regions positioned between the ctene-rows perpendicular to the tentacular axis ('?'; Figure 3B), whose cell-lineage is still unknown.

\section{Downregulation of $M I B$-catenin signaling affects endomesodermal but not ectodermal}

\section{differentiation}

Previous studies have shown that $M l ß$-catenin RNA transcripts are only detectable by in situ hybridization at the blastopore at 4 to $5 \mathrm{hpf}$ (33), suggesting that zygotic expression starts after mesodermal cells have already internalized in the embryo. Later, $M l ß$-catenin transcripts are ubiquitously expressed in the entire embryo (33). These observations suggest that Mlß-catenin has maternal and zygotic roles during $M$. leidyi embryogenesis. Unfortunately, we do not have the technical capability yet to dissect the roles of maternal loaded proteins during the first stages of ctenophore development. Instead, we assessed the putative role of $M l \beta$-catenin after its zygotic expression by mRNA overexpression of recombinant $L v$-cadherin (Figure 4$)(5,12)$ and CRRISPR/Cas9 knock-outs (Figure S7) delivered by microinjection into the uncleaved zygote.

The overexpression of this exogenous protein (cytoplasmic domain of $L v$-cadherin) has been deployed in other systems to sequester cytoplasmic $\beta$-catenin and inhibit its function $(5,9$, $12,16,41)$. We did not observed changes in the cleavage pattern or phenotypes during earlier stages compared to controls (Dextran or Histone::RFP (Movie S2) injected embryos). Hence, embryos overexpressing $L v$-cadherin where scored after $24 \mathrm{hpf}$ at cydippid stage by DIC confocal in vivo imaging (Figure $4 \mathrm{~A})$. All of the $L v$-cadherin injected embryos (50/50) lacked internal endodermal and 'mesodermally' derived tissues (gut and musculature) but developed ectodermal structures (comb plates, apical organ/dome cilia, ectodermal pharynx, and epidermal tissue) and some mesenchymal cells (Figure 5). Interestingly, some of the injected embryos

$180(9 / 50)$ displayed slightly different phenotypes: shorter pharynx elongation and absence of tentacular sheaths (Figure 4A: panels 3 and 4). This is probably because due to different levels of 
expression $L v$-cadherin. We obtained similar preliminary phenotypes using CRISPR/Cas 9 knock-outs of $M l ß$-catenin gene (supplementary material; Figure S7).

DISCUSSION

\section{The ancestral role of $\beta$-catenin is cell-specification but not cell-cell adhesion}

The structure and function of $ß$-catenin protein is highly conserved across all described metazoans. It was originally described, along with its closely related alpha catenin, to be associated with cell adhesion $(42,43)$ and only later shown to be involved in the nuclear 195 where $\beta$-catenin primary structure is conserved. Mlß-catenin possesses armadillo repeats flanked by the N-terminal (cortical and AJs binding) and C-terminal (nuclear role as transcriptional cofactor) characteristic domains (32-34).

Interestingly, the M. leidyi and P. pileus genomes do not contain the components for essential signaling pathways (e.g., Wnt/PCP, Notch, hedgehog) and bilaterian gene regulatory networks (e.g 'mesodermal' and neural GRNs) that regulate the nuclear signalization of $\beta$ catenin protein in other metazoans $(30,34,35,44)$. Thus, due to the highly conserved function in bilaterians + cnidarians, the highly conserved protein sequence of ctenophore beta catenin, and the possible role of a $\beta$-catenin-like armadillo gene involved in cell aggregation in slime molds (36), it strongly suggests the ancestral role of $\beta$-catenin would be as a member of AJs and/or cell adhesion. However, recent studies have shown that ctenophore cadherin protein structure does not possess the catenin binding domains in its C-terminal domain (34). This prediction is borne out from our immunolocalization studies where we never see $\beta$-catenin localized to cell junctions (Figures 2 and 3), as in the cnidarian Nematostella vectensis $(18,22)$ and other bilaterians $(5,19$, $26,34,45)$. Hence, regardless of the conservation of $M l ß$-catenin structure, $M$. leidyi tissues do not develop catenin-mediated AJs that mediate cell-cell adhesion. 
Here, for the first time, we show the spatiotemporal localization of $\beta$-catenin protein and the zygotic role of $M l ß$-catenin protein during the early embryogenesis of the ctenophore $M$. leidyi. We show that Mlß-catenin only displays cytosolic and nuclear localization during the observed developmental stages (Figures 2 and 3 ) and the zygotic protein is required for the differentiation of endo- and 'mesodermally' derived tissues (Figure 4). Therefore, we suggest that the ancestral role of $\beta$-catenin is associated with cell specification and not with the formation of AJs or other roles in cell adhesion.

Moreover, the observation of $\mathrm{n} M l \beta$-catenin and $M l \mathrm{Dvl}$ (a cortical marker for Wnt signaling) in the zygote before and after the first cleavage at the animal pole (Figure 2 and S5) suggests that these proteins could be related to animal-vegetal axis specification displaying different maternal and zygotic roles (see extensive discussion in supplementary material). The localization of maternal $\mathrm{n} M l \beta$-catenin in animal macromeres, and then, exclusively in endodermal cells (Figure 3; 4 hpf) suggest that maternal Mlß-catenin has roles in specifying endomesoderm during early gastrulation (and hence, the site of gastrulation) between 3 to 4 hpf. These observations indicate that some of the developmental roles of maternally loaded $ß$-catenin and Dvl proteins are conserved across Metazoa (4, 5, 14-17, 19, 25, 27, 6-13).

\section{The interesting case of the ctenophore middle germ layer}

More than the $95 \%$ of the extant animals are contained within the Bilateria. The ancestor of all bilaterian animals possessed three distinct germ layers: the ectoderm, endoderm, and mesoderm $(1,2,46)$. Each germ layer is specified by a highly conserved set of GRNs and cellular mechanisms present across Bilateria and Cnidaria, even though the latter does not develop a distinct third layer $(8,27,47)$. This fact brings the notion of tissues being organized by conserved molecular modules that interact together to organize cellular mechanisms orchestrating organismal development $(34,48-50)$. For example, in Bilateria and Cnidaria, the canonical Wnt/ß-catenin signaling pathway is finely regulated by the interaction between AJs and 'mesodermal' genes induced by the nuclear translocation of $\beta$-catenin $(18,19,21,25,26$, 45). 
Similarly, this study shows the first molecular evidence consistent with the presence of three different germ-cell layers characterized by the differential nuclearization of $\beta$-catenin protein in a ctenophore embryo (Figure 3$)$. Similar to bilaterian and cnidarian embryos $(4,5,14-$ $17,51,52,6-13), \mathrm{n} M l B$-catenin is present only in endodermal progenitor cells during early gastrulation (3-4 hpf) and can be used as a marker to identify the site of gastrulation and distinct germ layers. However, ctenophores do not have the AJs, signaling pathways 'modules,' nor the GRNs that contribute to mesodermal specification in their bilaterian and cnidarian relatives (30, $34,35,50,53)$ bringing into question the homology of the middle germ layer in ctenophores. In other words, like bilaterians, ctenophores develop three distinct germ cell-layers, but they do it by different molecular mechanisms.

In this context, it is unclear how we establish homologies when we compare the specification of distinct germ layers across Metazoa. Is the differential localization of $\mathrm{n} ß$-catenin in the prospective endoderm during gastrulation definitive evidence that establishes germ layer homology? This would imply that, regardless the lack of genomic content in ctenophores, the role of nß-catenin specifying germ layers during early development is conserved across Metazoa. Thus, the cells of ctenophore germ layers could be considered to be homologous with other endomesodermal cells of bilaterians and cnidarians, but that the origin of mesoderm proper could be an independent event. The consideration of this option would also imply that cnidarians, whose genomes and cells possess the necessaries molecular and cellular mechanisms to segregate a distinct mesoderm (18), have lost the natural ability to develop a spatially distinct third germ layer.

If, on the other hand, we define the three distinct bilaterian-germ layers (ecto, endo, and mesoderm) on the basis of evolutionary conserved GRNs and or interactions between signaling pathways and not on morphological criteria, then, cnidarians but not ctenophores have germ layers homologous to bilaterians. This hypothesis would imply that the segregation of a distinct middle layer has two independent origins in Metazoa $(28,30,31)$. In this scenario, it could have been possible that the emergence of full sets of molecular modules (e.g., AJs, SJs, Wnt/PCP signaling pathway, and mesodermal genes like twist and snail) rearranged the organization of 
cell-tissues $(30,34,35)$. Such evolutionary event may have brought together new interactions between signaling pathways (e.g., junctional localization of B-catenin) that would have led the emergence of a new epithelial tissue, the loss of a distinct third germ layer in cnidarians, and the later emergence of bilaterian-mesoderm (Figure 5).

In summary, we show that not only the structure but also the role of nß-catenin as a molecular marker to specify the site of gastrulation during early development is conserved across Metazoa (Figures 3 and S3). However, ctenophores do not have the mechanisms regulating the nuclearization of this protein that are necessary to differentiate distinct germ layers in other metazoans $(18,30,33-35)$. Furthermore, the identity of the third distinct germ layer in ctenophore embryos might not be homologous to any other studied animal because of the absence of the GRNs that determine the bilaterian-mesoderm $(8,27,47)$. Hence, until we identify the molecular components (and their functional interactions) that are deployed to tissue specification in ctenophores, we cannot discard any hypothesis with the available information. The development of temporal trajectories of single cell-seq and proteomic analyses of different cell lineages will give us the definite molecular candidates to experimentally test in a large phylogenetically scale. In the meantime, we suggest giving a new terminology to identify ctenophore 'mesoderm' (showed in quotation through the text) in order to highlight its different molecular identity. We suggest using the indigenous word Taypi (IPA: 'tai.pi) that in the Aymara language (South American) refers to a central (middle) place of encounter (where two different entities encounter each other), reflecting the embryological nature of cells that reside in the "middle layer" in ctenophores. 


\section{REFERENCES}

1. M. Q. Martindale, The evolution of metazoan axial properties. Nat. Rev. Genet. 6, 917927 (2005).

2. M. Q. Martindale, A. Hejnol, A developmental perspective: changes in the position of the blastopore during bilaterian evolution. Dev. Cell. 17, 162-174 (2009).

3. M. Q. Martindale, P. N. Lee, The Development of Form: Causes and Consequences of Developmental Reprogramming Associated with Rapid Body Plan Evolution in the Bilaterian Radiation. Biol. Theory. 8, 253-264 (2013).

4. P. N. Lee, S. Kumburegama, H. Q. Marlow, M. Q. Martindale, A. H. Wikramanayake, Asymmetric developmental potential along the animal-vegetal axis in the anthozoan cnidarian, Nematostella vectensis, is mediated by Dishevelled. Dev. Biol. 310, 169-186 (2007).

5. C. Y. Logan, J. R. Miller, M. J. Ferkowicz, D. R. McClay, Nuclear beta-catenin is required to specify vegetal cell fates in the sea urchin embryo. Development. 126, 345357 (1999).

6. J. Q. Henry, K. J. Perry, M. Q. Martindale, $\beta$-catenin and Early Development in the Gastropod, Crepidula fornicata. Integr. Comp. Biol. 50, 707-719 (2010).

7. S. Darras, J. Gerhart, M. Terasaki, M. Kirschner, C. J. Lowe, $\beta$-catenin specifies the endomesoderm and defines the posterior organizer of the hemichordate Saccoglossus kowalevskii. Development. 138, 959-970 (2011).

8. E. Röttinger, P. Dahlin, M. Q. Martindale, A framework for the establishment of a cnidarian gene regulatory network for "endomesoderm" specification: the inputs of $\beta$ catenin/TCF signaling. PLoS Genet. 8, e1003164 (2012).

9. B. S. McCauley, E. Akyar, H. R. Saad, V. F. Hinman, Dose-dependent nuclear ß-catenin response segregates endomesoderm along the sea star primary axis. Development. 142, 207-217 (2014).

10. J. Huelsken et al., Requirement for beta-catenin in anterior-posterior axis formation in mice. J. Cell Biol. 148, 567-578 (2000).

11. K. S. Imai, Isolation and characterization of beta-catenin downstream genes in early 
embryos of the ascidian Ciona savignyi. Differentiation. 71, 346-360 (2003).

12. A. H. Wikramanayake et al., An ancient role for nuclear catenin in the evolution of axial polarity and germ layer segregation. Nature. 426, 446-450 (2003).

13. H. E. Weitzel et al., Differential stability of beta-catenin along the animal-vegetal axis of the sea urchin embryo mediated by dishevelled. Development. 131, 2947-2956 (2004).

14. H. Nishida, Specification of embryonic axis and mosaic development in ascidians. Dev. Dyn. 233, 1177-1193 (2005).

15. S. Q. Schneider, B. Bowerman, beta-Catenin asymmetries after all animal/vegetaloriented cell divisions in Platynereis dumerilii embryos mediate binary cell-fate specification. Dev. Cell. 13, 73-86 (2007).

16. J. Q. Henry, K. J. Perry, J. Wever, E. Seaver, M. Q. Martindale, Beta-catenin is required for the establishment of vegetal embryonic fates in the nemertean, Cerebratulus lacteus. Dev. Biol. 317, 368-379 (2008).

17. T. Momose, R. Derelle, E. Houliston, A maternally localised Wnt ligand required for axial patterning in the cnidarian Clytia hemisphaerica. Development. 135, 2105-2113 (2008).

18. M. Salinas-Saavedra, A. Q. Rock, M. Q. Martindale, Germ layer-specific regulation of cell polarity and adhesion gives insight into the evolution of mesoderm. Elife. 7 (2018), doi:10.7554/eLife.36740.

19. W. J. Nelson, R. Nusse, Convergence of Wnt, $\beta$-Catenin, and Cadherin pathways. Science (80-. ). 303, 1483-1487 (2004).

20. P. N. Lee, K. Pang, D. Q. Matus, M. Q. Martindale, A WNT of things to come: evolution of Wnt signaling and polarity in cnidarians. Semin. cell \&amp; Dev. Biol. 17, 157-167 (2006).

21. G. Schäfer, M. Narasimha, E. Vogelsang, M. Leptin, Cadherin switching during the formation and differentiation of the Drosophila mesoderm - implications for epithelial-tomesenchymal transitions. J. Cell Sci. 127, 1511-1522 (2014). domain in Nematostella requires $\beta$-catenin and the opposing activities of Six3/6and Frizzled5/8. Development. 143, 1766-1777 (2016). 
23. K. M. Loh, R. van Amerongen, R. Nusse, Generating Cellular Diversity and Spatial Form: Wnt Signaling and the Evolution of Multicellular Animals. Dev. Cell. 38, 643-655 (2016).

24. A. Alok et al., Wnt proteins synergize to activate $\beta$-catenin signaling. J. Cell Sci. 130, 1532-1544 (2017).

25. R. Nusse, H. Clevers, Wnt/ß-Catenin Signaling, Disease, and Emerging Therapeutic Modalities. Cell. 169, 985-999 (2017).

26. M. Weng, E. Wieschaus, Polarity protein Par3/Bazooka follows myosin-dependent junction repositioning. Dev. Biol. 422, 125-134 (2017).

27. E. H. Davidson, D. H. Erwin, Gene Regulatory Networks and the Evolution of Animal Body Plans. Science (80-. ). 311, 796-800 (2006).

28. C. W. Dunn et al., Broad phylogenomic sampling improves resolution of the animal tree of life. Nature. 452, 745-749 (2008).

29. A. Hejnol et al., Assessing the root of bilaterian animals with scalable phylogenomic methods. Proc. Biol. Sci. 276, 4261-4270 (2009).

30. J. F. Ryan et al., The Genome of the Ctenophore Mnemiopsis leidyi and Its Implications for Cell Type Evolution. Science (80-. ). 342, 1242592 (2013).

31. N. V Whelan et al., Ctenophore relationships and their placement as the sister group to all other animals. Nat. Ecol. \&amp; Evol., 1-10 (2017).

32. S. Q. Schneider, J. R. Finnerty, Protein evolution: structure-function relationships of the oncogene beta-catenin in the evolution of multicellular animals. J. Exp. ... (2003), doi:10.1002/jez.b.00006.

33. K. Pang et al., Genomic insights into Wnt signaling in an early diverging metazoan, the ctenophore Mnemiopsis leidyi. Evodevo. 1, 10 (2010).

34. H. Belahbib et al., New genomic data and analyses challenge the traditional vision of animal epithelium evolution. BMC Genomics. 19, 393 (2018).

35. P. Ganot et al., Structural molecular components of septate junctions in cnidarians point to the origin of epithelial junctions in eukaryotes. Mol. Biol. Evol. 32, 44-62 (2015). 
catenin predates cadherin and metazoan origins. Science (80-. ). 331, 1336-1339 (2011).

37. M. Q. Martindale, J. Q. Henry, Intracellular fate mapping in a basal metazoan, the ctenophore Mnemiopsis leidyi, reveals the origins of mesoderm and the existence of indeterminate cell lineages. Dev. Biol. 214, 243-257 (1999).

40. D. Carré, C. Rouvière, C. Sardet, In vitro fertilization in ctenophores: sperm entry, mitosis, and the establishment of bilateral symmetry in Beroe ovata. Dev. Biol. 147, 381391 (1991).

41. J. Heasman, A. Crawford, K. Goldstone, Overexpression of cadherins and underexpression of $\beta$-catenin inhibit dorsal mesoderm induction in early Xenopus embryos. Cell. 79, 791-803 (1994).

42. H. Oda, M. Takeichi, Structural and functional diversity of cadherin at the adherens junction. J. Cell Biol. 193, 1137-1146 (2011).

43. P. D. McCrea, C. J. Gottardi, Beyond $\beta$-catenin: prospects for a larger catenin network in the nucleus. Nat. Publ. Gr. 17, 55-64 (2015).

44. L. L. Moroz et al., The ctenophore genome and the evolutionary origins of neural systems. Nature. 510, 109-114 (2014).

45. M. Weng, E. Wieschaus, Myosin-dependent remodeling of adherens junctions protects junctions from Snail-dependent disassembly. J. Cell Biol. 212, 219-229 (2016).

46. U. Technau, C. B. Scholz, Origin and evolution of endoderm and mesoderm. Int. J. Dev. Biol. 47, 531-539 (2003).

47. T.-M. Chan et al., Developmental gene regulatory networks in the zebrafish embryo. Biochim. Biophys. Acta. 1789, 279-298 (2009).

48. S. A. Newman, R. Bhat, Dynamical patterning modules: a \&quot;pattern language\&quot; for development and evolution of multicellular form. Int. J. Dev. Biol. 53, 693-705 
(2009).

49. Y. Bernadskaya, L. Christiaen, Transcriptional Control of Developmental Cell Behaviors. Annu. Rev. Cell Dev. Biol. 32, 77-101 (2016).

50. L. S. Babonis, M. Q. Martindale, Phylogenetic evidence for the modular evolution of metazoan signalling pathways. Philos. Trans. R. Soc. B Biol. Sci. 372, 2015041920150477 (2017).

51. R. Dumollard, C. Hébras, L. Besnardeau, A. McDougall, Beta-catenin patterns the cell cycle during maternal-to-zygotic transition in urochordate embryos. Dev. Biol. 384, 331342 (2013).

52. A. T. Baldwin, B. T. Phillips, in Perspectives in Translational Cell Biology, P. B. T.-C. P. in D. and D. Michael Conn, Ed. (Academic Press, Boston, 2018), pp. 61-102.

53. C. R. Magie, M. Q. Martindale, Cell-cell adhesion in the cnidaria: insights into the evolution of tissue morphogenesis. Biol. Bull. 214, 218-232 (2008).

Acknowledgments: We thank C.E. Schnitzler and J. Ryan for technical assistance with the ctenophore genome.

Funding: This research was supported by the NSF IOS-1755364 and NASA 16-EXO16_2-0041 from MQM.

Author contributions: MS-S., and MQM. designed research and analyzed data with collaboration of AHW. MS-S. performed research with help of MQM. AHW design and developed MlDvl antibody. MS-S., and MQM. wrote the manuscript with collaboration of AHW. All authors read and approved the final manuscript.

Competing interests: The authors declare no competing interests.

Data and materials availability: All data is available in the main text or the supplementary materials. 
FIGURES AND LEGENDS

A

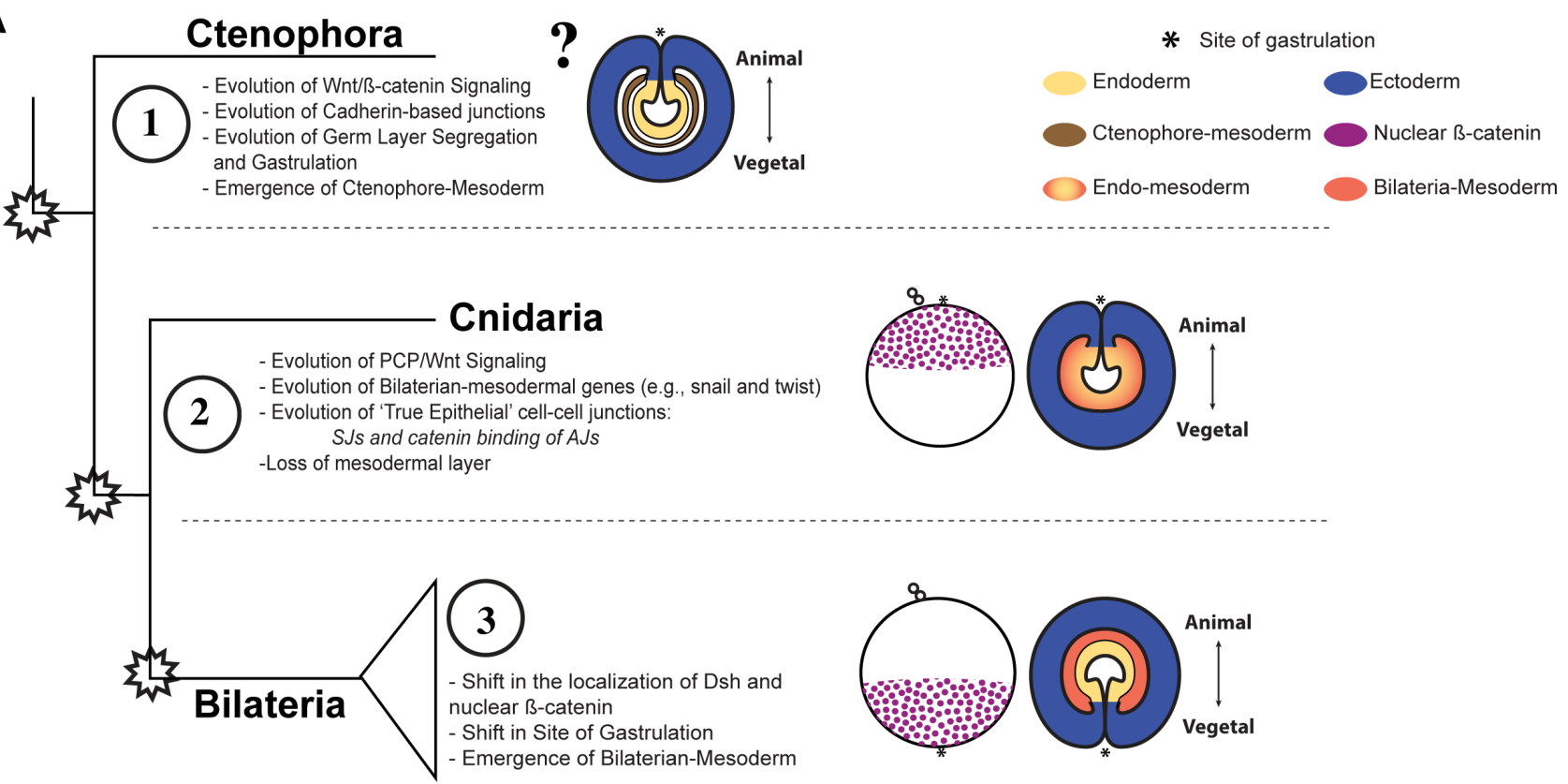

B

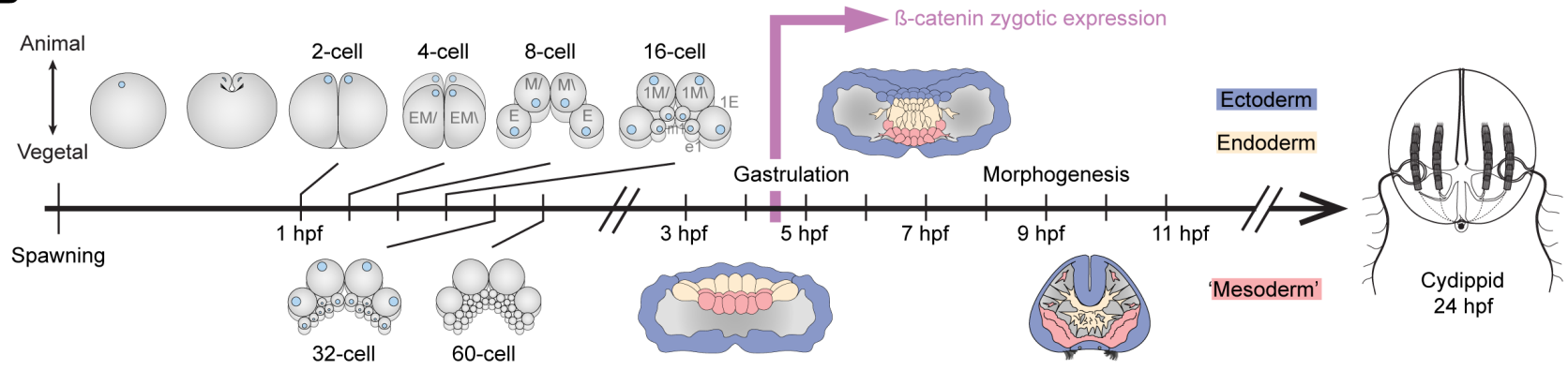

Figure 1. Evolution of Wnt signaling components during the animal evolution. A)

Three major evolutionary steps (left side) that might have changed the organization of gastrulation in the Metazoa. The diagram (right side) depicts the site of gastrulation and the nuclear localization of $ß$-catenin during the development of Cnidaria and Bilateria. However, there are no descriptions available for ctenophore cells B) The stereotyped early development of $M$. leidyi. M. leidyi ß-catenin zygotic expression is temporally depicted. 

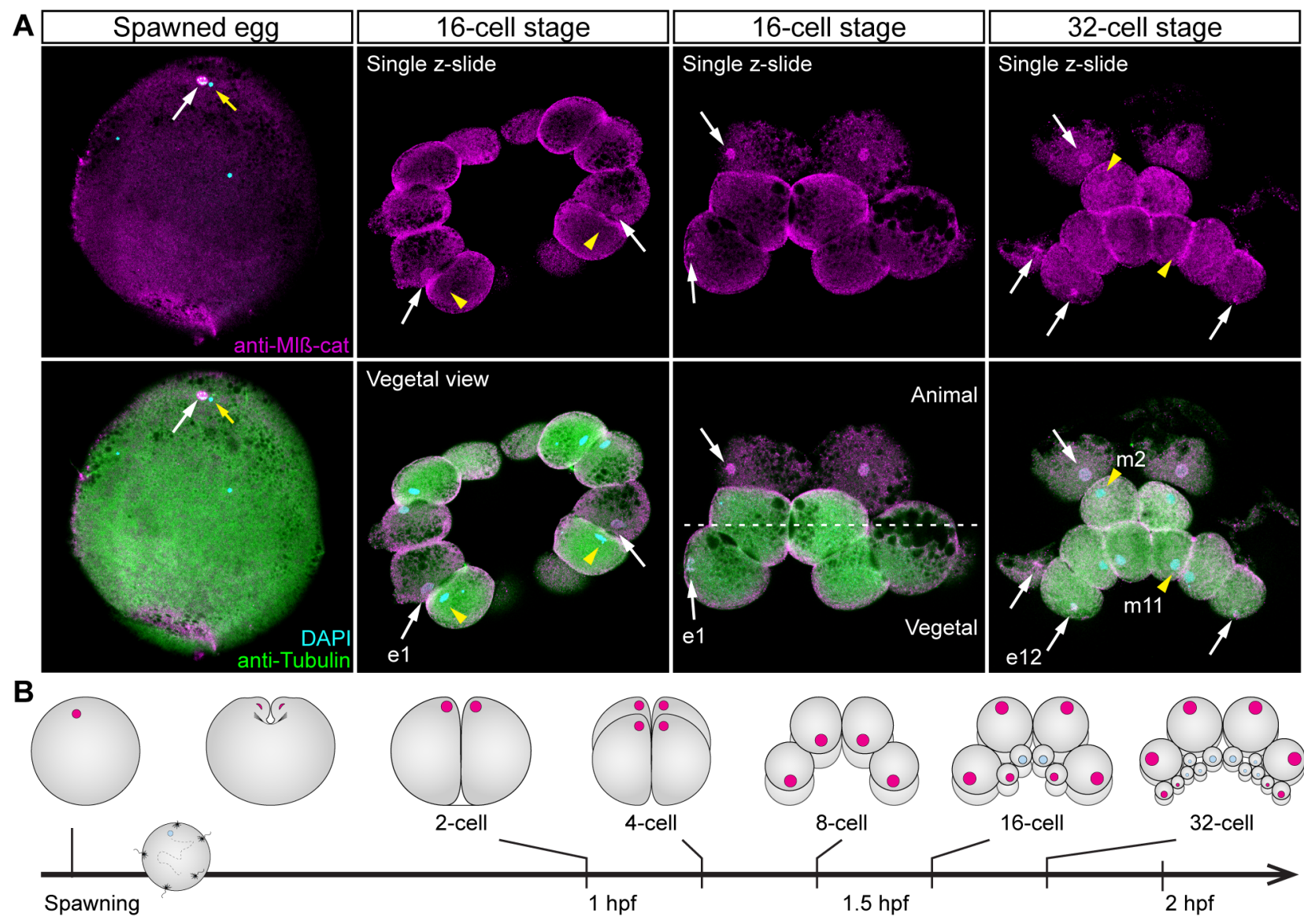

Figure 2. MIß-catenin protein localizes in the nucleus of the eggs and in every blastomere until the 16-cell stage. A) Immunostaining against M/ß-catenin during cleavage stages of $M$. leidyi development. Nuclear M/ß-catenin (white arrows) was not detected in the middle vegetal micromeres (yellow arrowheads) at 16-cell and 32-cell stages. Images are single optical sections from a z-stack confocal series. Orientation axes are depicted in the figure. B) Diagram depicting the nuclear localization of $M / ß$-catenin. Animal pole is to the top as depicted in $A$. Morphology is shown by DAPI and Tubulin immunostainings. Homogeneous cytosolic staining was digitally reduced. See Figure S2 for further details. 
Figure 3. MIß-catenin protein dynamics during and after M. leidyi gastrulation. A) Immunostaining against $M / ß$-catenin during gastrulation stages of $M$. leidyi development. MIß-catenin protein localizes in the nuclei of prospective endodermal cells (white arrowheads). MIß-catenin protein is nuclear in subset of vegetal ectodermal cells at $4 \mathrm{hpf}$ (White arrows). M/ß-catenin protein transiently localizes in the nuclei of every cell at $5 \mathrm{hpf}$; white arrows indicate ectodermal cells. B) Between 6-7 hpf, nuclear M/ß-catenin is only observable in endodermal (white arrowheads) and 'mesodermal' cells (yellow arrows). MIß-catenin protein transiently localizes in the nuclei of every cell at $8 \mathrm{hpf}$ but it regionalizes after 9 hpf. MIß-catenin protein localizes in the nuclei of epidermal ectodermal cells (White arrows), pharyngeal cells (yellow arrowhead) endodermal cells (white arrowheads), and 'mesodermal' cells (yellow arrow). See Figure S3 for further details. Orientation axes and germ layers are depicted in the figure: Animal/Oral pole is to the top. Ecto: Ectoderm. Endo: Endoderm. 'Meso': 'mesoderm.' A.O.: prospective Apical Organ. '*': prospective comb plates. phx: pharynx. Ts:

Tentacle sheath. Ta: Tentacle apparatus. c.p.: comb plates. '?': unknown tissue. No cortical localization was observed at the cell-contact region. Images are 3D reconstructions from a z-stack confocal series. Homogeneous cytosolic staining was digitally reduced. Morphology is shown by DAPI and Tubulin immunostainings. C) Diagram depicting the nuclear localization of MIß-catenin. Upper row: lateral view. Lower row: aboral view. 
bioRxiv preprint doi: https://doi.org/10.1101/520957; this version posted January 17,2019 . The copyright holder for this preprint (which was not certified by peer review) is the author/funder, who has granted bioRxiv a license to display the preprint in perpetuity. It is made available under aCC-BY-NC-ND 4.0 International license.
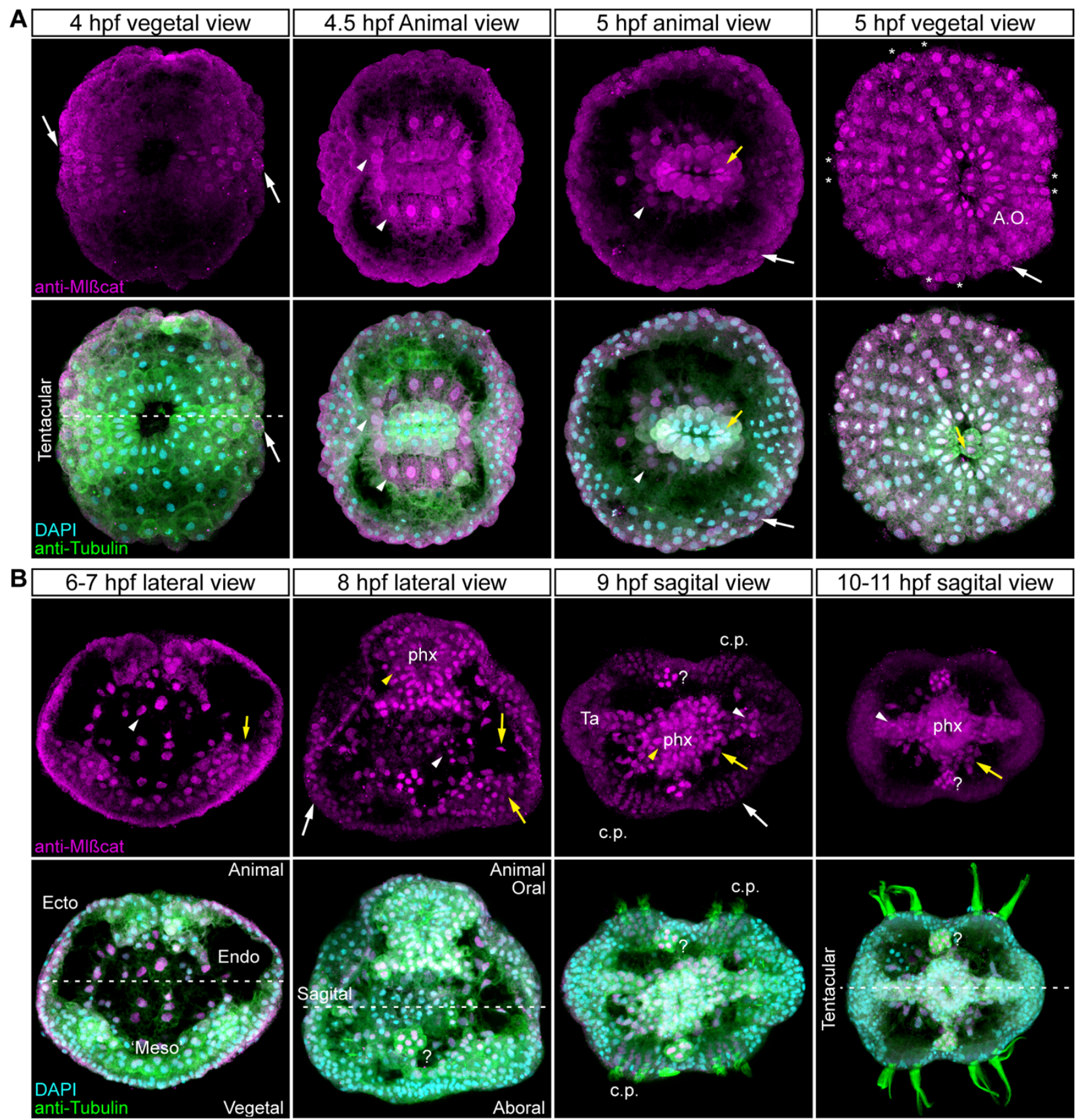

C Endoderm 'Mesoderm'

\section{Nuclear ß-catenin}
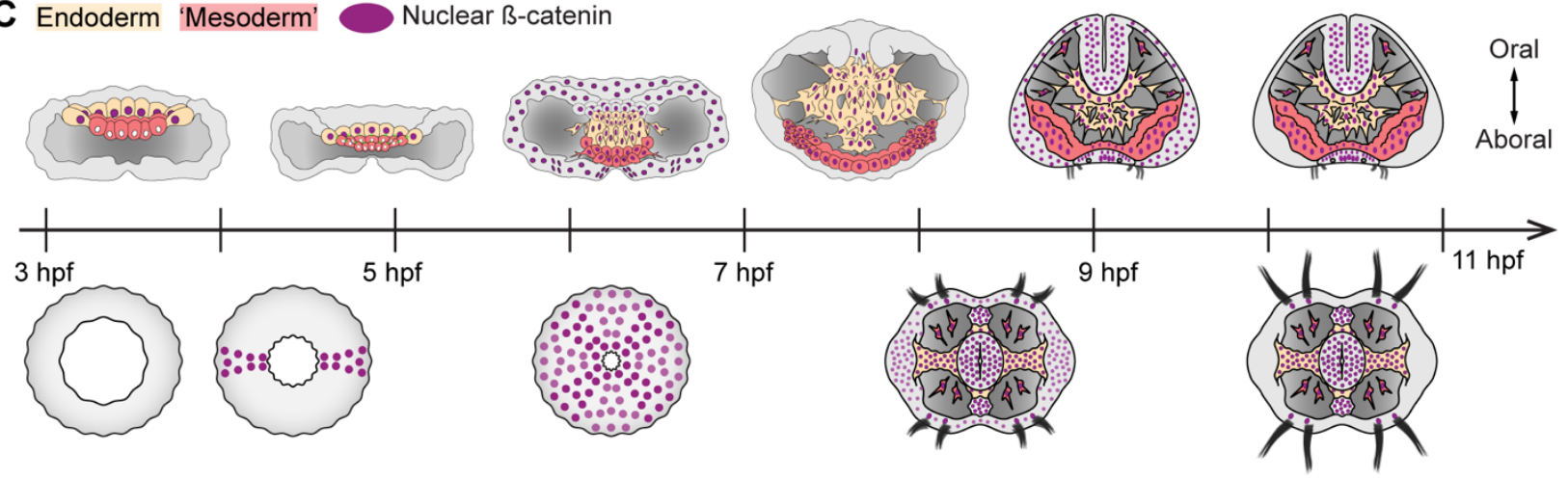


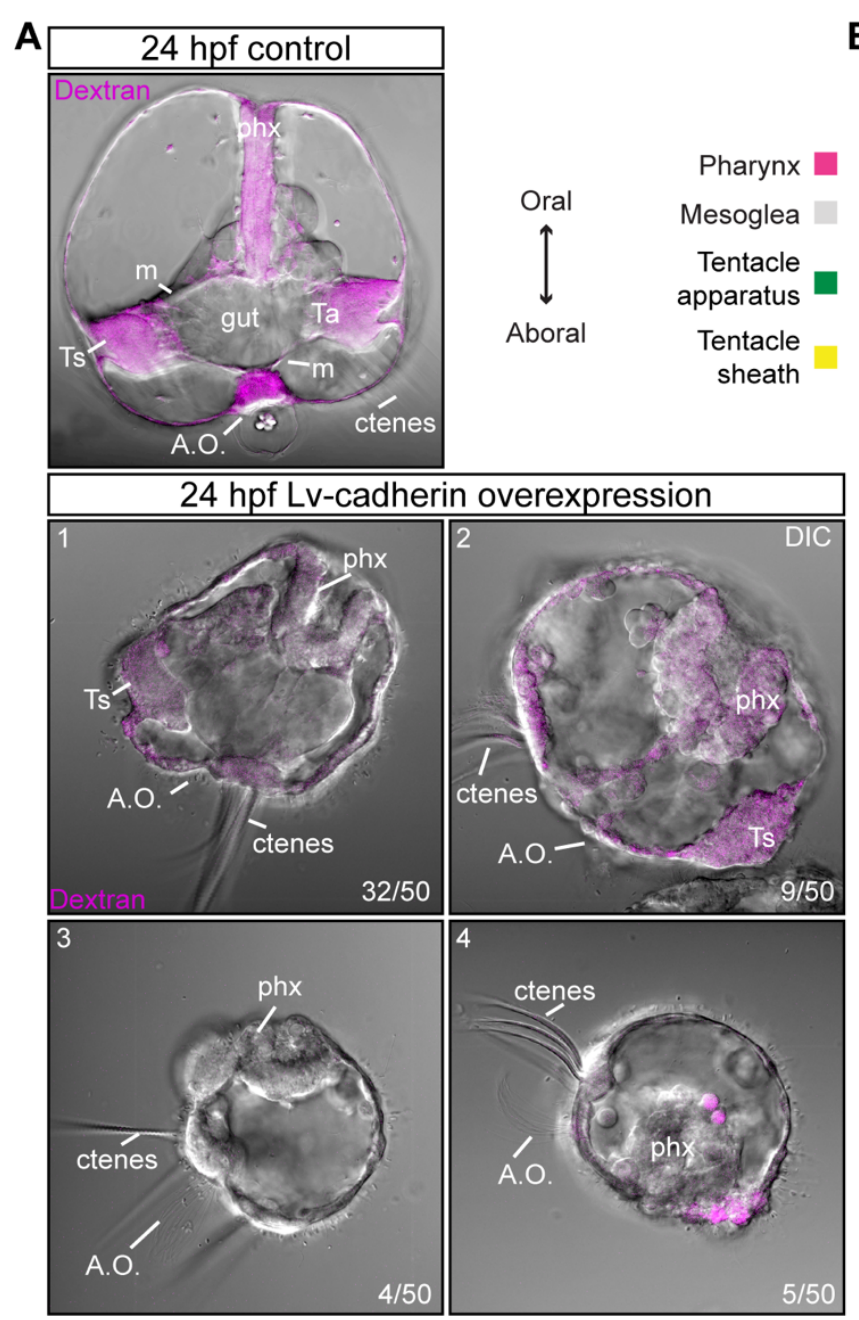

B
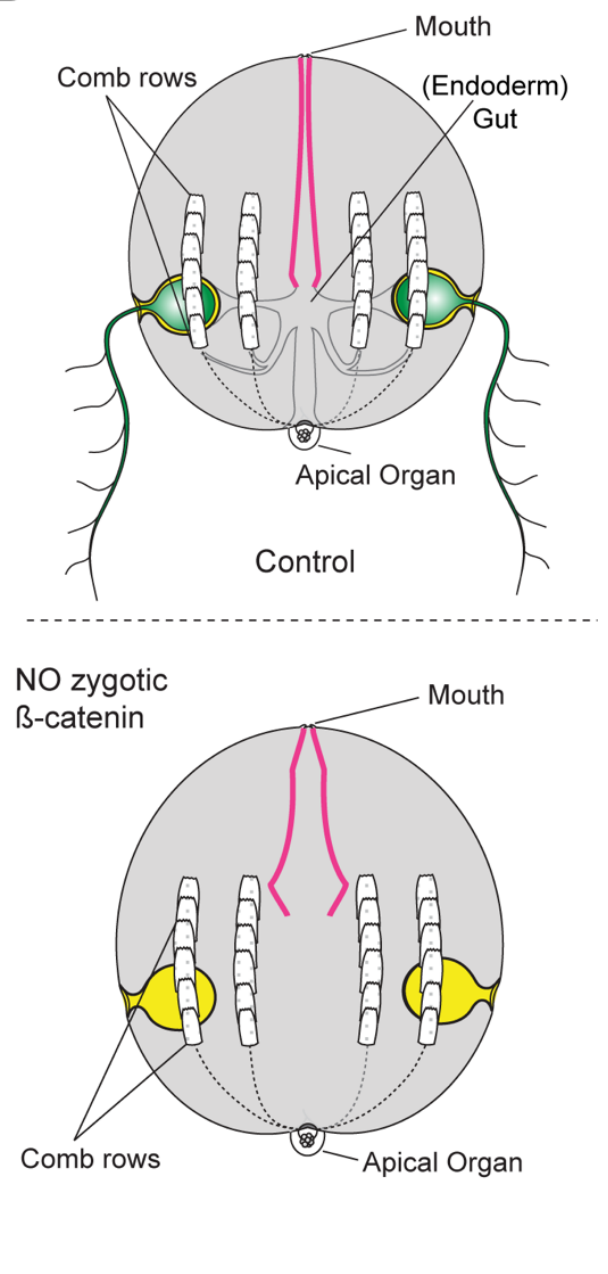

Figure 4. Testing the function of zygotic MIß-catenin. A) Overexpression of the mRNA encoding for the cytoplasmic domain of $L v$-cadherin. Injected embryos lacked internal tissues including musculature ('m') and gut but developed ectodermal structures such as comb plates (ctenes), apical organ (A.O.), ectodermal pharynx (phx), and epidermal tissue as is depicted in B. Four slightly different phenotypes are shown in A. Ts: Tentacle sheath. Ta: tentacle apparatus. Similar results were obtained using CRRISPR/Cas9 knock-outs of MIß-catenin gene (Figure S6). 
A
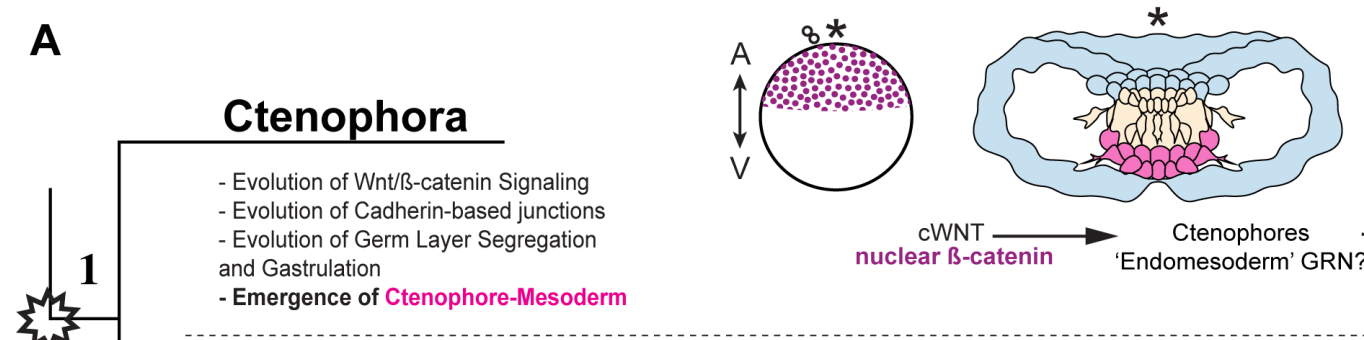

Ectoderm

nuclear ß-catenin 'Endomesoderm' GRN?

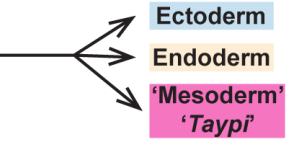

\section{Cnidaria}

- Evolution of PCP/Wnt Signaling

- Evolution of Bilaterian-mesodermal genes (e.g., snail and twist)

- Evolution of 'True Epithelial' cell-cell junctions:

2 SJs and catenin binding of AJS

-Loss of mesodermal layer
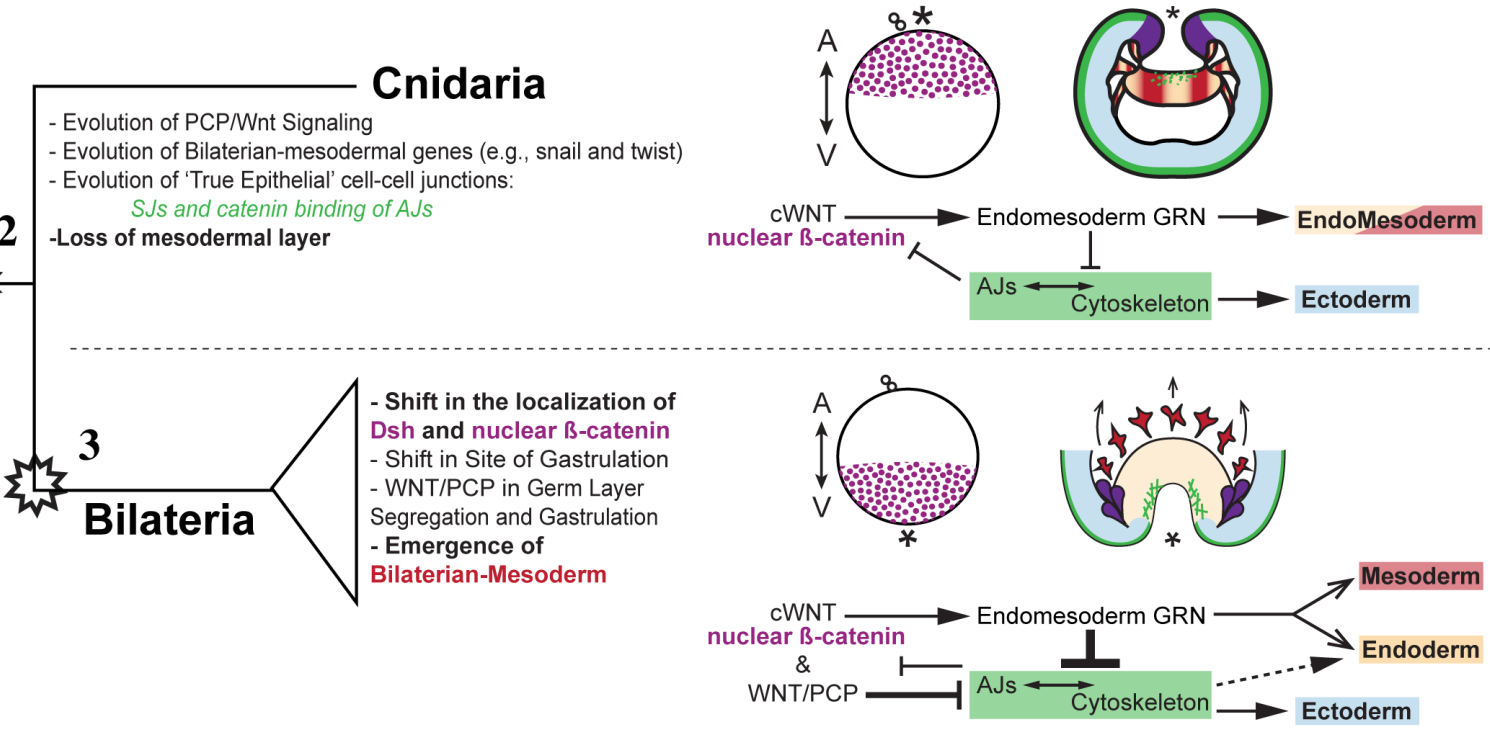

B
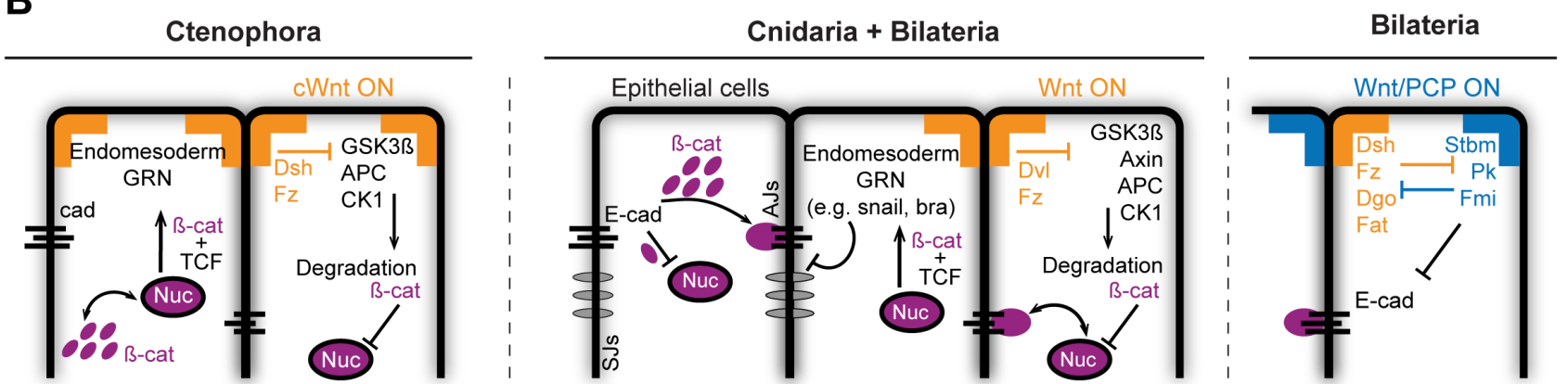

Figure 5. Evolution of $ß$-catenin regulation and gastrulation in Metazoa. A) The emergence of full sets of molecular modules rearranged the organization of cell-tissues that regulates the segregation of distinct germ layers. B) Diagram depicting the evolution of different interactions between known signaling pathways that ß-catenin localization in the Metazoa, including the new information obtained by this study during the early development of the ctenophore M. leidyi. Ctenophores do not have cell-cell adhesion complexes that regulate the localization of $ß$-catenin in cnidarian and bilaterian cells during gastrulation. In addition, the regulation of the $\mathrm{Wnt} / \mathrm{ß}$-catenin specification signaling by the Wnt/PCP signaling pathway appears to be present in bilaterian but not in cnidarians embryos. 


\section{SUPPLEMENTARY MATERIALS}

\section{Materials and Methods}

\section{Culture and Spawning of M. leidyi}

Spawning, gamete preparation, fertilization and embryo culturing of $M$. leidyi embryos was performed as previously described (1). Adult M. leidyi were maintained at the Whitney Laboratory for Marine Bioscience of the University of Florida (USA). Spawning was induced by incubating the adults under a three to four-hour dark cycle at room temperature. The embryos were kept in glass dishes (to prevent sticking) in filtered 1x seawater at room temperature until the desired stage.

\section{$\underline{\text { Western Blot }}$}

Western blots were carried out as described $(2,3)$ using adult tissue lysates dissected by hand in order to discard larger amount of mesoglea. Antibody concentrations for Western blot were 1:1,000 for all antibodies tested.

\section{Immunohistochemistry}

All immunohistochemistry experiments were carried out using the previous protocol for $M$. leidyi (1). Embryos were fixed on a rocking platform at room temperature. Embryos of different stages were fixed for 2 hours in fresh Fixative (100mM HEPES pH 6.9; 0.05M EGTA; 5mM MgSO4; 200mM NaCl; 1x PBS; 3.7\% Formaldehyde; 0.2\% Glutaraldehyde; 0.2\% Triton X-100; and 1X fresh sea water). Fixed embryos were rinsed at least five times in PBT (PBS buffer plus $0.1 \%$ BSA and $0.2 \%$ Triton X-100) for a total period of 3 hours. PBT was replaced with 5\% normal goat serum (NGS; diluted in PBT) and fixed embryos were blocked for 1 to 2 hours at room temperature with gentle rocking. Primary antibodies were diluted in 5\% NGS to desired concentration. Blocking solution was removed and replaced with primary antibodies diluted in NGS. All antibodies incubations were conducted over night on a rocker at $4{ }^{\circ} \mathrm{C}$. After incubation of the primary antibodies, samples were washed at least five times with PBT for a total period of 3 hours. Secondary antibodies were then applied (1:250 in 5\% NGS) and samples were left on a rocker overnight at $4{ }^{\circ} \mathrm{C}$. Samples were then washed with PBT and left on a rocker at room temperature for an hour. Samples were then washed once with PBT and incubated with DAPI $(0.1 \mu \mathrm{g} / \mu 1$ in PBT; Invitrogen, Inc. Cat. \# D1306) for 1 hour to allow nuclear visualization. Stained samples were rinsed 
again in PBS two times and dehydrated quickly into isopropanol using the gradient 50\%, 75\%, 90\%, and 100\%, and then mounted in Murray's mounting media (MMM; 1:2 benzyl benzoate:benzyl alcohol) for visualization. Note that MMM may wash DAPI out of your sample. We scored more than 1,000 embryos per each antibody staining and confocal imaged more than 50 embryos at each stage obtaining similar staining patterns for each case.

The primary antibodies and concentrations used were: mouse anti-alpha tubulin (1:500; SigmaAldrich, Inc. Cat.\# T9026. RRID:AB_477593). Secondary antibodies are listed in Key resources table (Table 1).

Rabbit anti-Mlß-cat antibody is custom made high affinity-purified peptide antibodies that were raised by Bethyl labs Inc.. Affinity-purified $M$. leidyi anti- $\beta$-catenin (anti-Mlß-cat) peptide antibody was raised against a selected amino acid region of the Mlß-catenin (METPVYQELS; Bethyl Inc., Montgomery, TX, USA). Rabbit anti-MlDvl antibody is custom made high affinity-purified against the DIX domain (recombinant protein) of $M l$ Dvl. Blast searches against the M. leidyi genome sequences showed that the amino acid sequences were not present in any predicted $M$. leidyi proteins other than the expected protein. Both antibodies are specific to M. leidyi proteins (Figure 2) and were diluted 1:100.

\section{$\underline{\text { mRNA Microinjections }}$}

The coding region for $M l ß$-catenin was PCR-amplified and cloned in frame with mScarlet into pCS2+ vector using NEBuilder® HiFi DNA Assembly (NEB, Inc. \#E2621S). Eggs were injected directly after fertilization as previously described for $N$. vectensis studies (2-4) with the mRNA encoding one or more proteins fused in frame with reporter fluorescent protein (N-terminal tag) using final concentrations of $300 \mathrm{ng} / \mu \mathrm{l}$ for each gene. Fluorescent dextran was also co-injected to visualize the embryos. Live embryos were kept at room temperature and visualized after the mRNA of the FP was translated into protein (4-5 hours). Live embryos were mounted in 1x sea water for visualization. Images were documented at different stages. We injected and recorded 20 embryos for each injected protein and confocal imaged each specimen at different stages for detailed analysis of phenotypes in vivo. We repeated each experiment at least five times obtaining similar results for each case. The fluorescent dextran and primers for the cloned genes are listed in Key resources table (Table 1).

\section{CRISPR/Cas9 Knock-Outs}


To target our gene of interest, we used synthetic guide RNAs (sgRNA; Synthego, Inc.) and followed the instructions obtained from the manufacturer to form the RNP complex with Cas9 (Cas9 plus sgRNAs). Target sites, off-target sites, and CFD scores were identified and sgRNA were designed using CRISPRscan $(5,6)$. We delivered the RNP complex by microinjection as previously described for N. vectensis studies (3). Lyophilized Cas9 (PNA Bio., Inc. Cat.\# CP01) was reconstituted in nuclease-free water with $20 \%$ glycerol to a final concentration of $2 \mu \mathrm{g} / \mu \mathrm{l}$. Reconstituted Cas 9 was aliquoted for single use and stored at $-80^{\circ} \mathrm{C}$. Embryos were injected, as described for mRNA microinjections, with a mixture $(12.5 \mu \mathrm{l})$ containing sgRNAs $(80 \mathrm{ng} / \mu \mathrm{l}$ of each sgRNA), Cas9 (3 $\mu \mathrm{g})$, and Alexa Fluor 488-dextran $(0.2 \mu \mathrm{g} / \mu \mathrm{l}$; Molecular Probes, Inc. Cat.\# D22910). Cas9 and sgRNA guides only controls were injected alongside each round of experiments. sgRNA guides controls are only shown in figures as Cas9 had no significative effects when microinjected. 3 sgRNA were used to knock out $M l \beta$-catenin. We injected and recorded more than 20 embryos for each treatment. We repeated each experiment at five times obtaining similar results for each case. sgRNAs' sequences and PCR primers flanking the targeted region are listed in Key resources table (Table $\mathrm{S} 1)$.

\section{Supplementary Text}

\section{Normal Development of M. leidyi}

The ctenophore M. leidyi develops by a highly stereotyped and synchronous cleavage program (Figure 1B) $(7,8)$. Many Sperm and eggs are subsequently released to the water column and fertilization takes place immediately at the time of spawning. The eggs of M. leidyi are polarized along the animal-vegetal axis and are fertilized by polyspermy $(9,10)$. Prior to syngamy, the egg pronucleus migrates in the cytosol, and after it 'choses' one of the spermatozoids, both pronuclei fuse and the first cleavage proceeds re-determining the animal-vegetal axis (10). The first cleavage furrow is observable at the animal pole 45-60 minutes post fertilization at room temperature $\left(25^{\circ} \mathrm{C}\right)$, is unipolar, and holoblastic. Subsequent rounds of division are also unipolar and occur at the apical surface of each blastomere every 10 to $20 \mathrm{~min}$. The second cleavage also passes through the animalvegetal axis perpendicular to the first cleavage plane and gives rise to four symmetric quadrants (the EM blastomeres). The third cleavage is oblique and forms four end (E) blastomeres towards the vegetal pole and four middle $(\mathrm{M})$ blastomeres at the animal pole. Each $\mathrm{M}$ blastomere undergoes two rounds of asymmetric division towards the vegetal pole, resulting in two small $\mathrm{m}$ micromeres $(\mathrm{m} 1$ 
and $\mathrm{m} 2$ ) and 'leaving' one $\mathrm{M}$ macromere at the animal pole. On the other hand, each vegetal E blastomere undergoes three asymmetric cell divisions, giving rise to three small e micromeres (e1, $\mathrm{e} 2$ and $\mathrm{e} 3$ ) at the vegetal pole and an E macromere displaced towards the animal pole. Cell divisions of micromeres continue, increasing the number of micromeres but maintaining the number of 8 macromeres at the animal pole. Gastrulation of $M$. leidyi embryos takes place about 3 hours post fertilization (hpf) by the migration towards the animal pole of e-descendant and m-micromere descendant micromeres that begin to envelop the macromeres via epiboly. The animal macromeres divide perpendicular to the oral-aboral axis forming a set of a subset of eight "oral" micromeres at the animal pole (prospective 'mesoderm') that remain attached to their mother macromeres (prospective endoderm) by their tubulin midbodies. At $4.5 \mathrm{hpf}$ the eight "oral" micromeres born at the animal pole (prospective 'mesoderm') divide and migrate between endodermal precursors towards the vegetal pole making direct contact with the vegetal ectoderm at $5 \mathrm{hpf}$. Gastrulation in $M$. leidyi embryos ends when the prospective ectodermal pharynx starts to invaginate at the animal (oral) pole around $6 \mathrm{hpf}$. At this stage, the internal morphology of the embryo is drastically modified. The endodermal cells (oral macromeres) start to divide and lose their distinct cellular structure forming a syncytial layer. 'Mesodermal' cells acquire mesenchymal morphologies and migrate laterally along the vegetal pole underneath the vegetal ectoderm, in the space located between the syncytial endoderm and the ectoderm. At $7 \mathrm{hpf}$, cells continue dividing with ectodermal thickenings invaginating to give rise to the future tentacle bulbs. The comb plates form around at 810 hpf. During these stages, all juvenile structures are already developed and the cydippid stage hatches from the egg membrane at 18-20 hpf.

Another characteristic of ctenophore development is the high level of mosaicism $(8)$. The site of the first cleavage is causally involved with the determination of the site of gastrulation and the future oral pole $(7,9,11)$. Each round of cell division partitions the maternal determinants asymmetrically into specific blastomeres that will develop into specific tissues. In other words, the bauplan of ctenophores is a direct consequence of the cleavage program until the gastrulation movements reorganize the final structure of the embryo. For example, the four EM blastomeres correspond to the four quadrants of the larval and adult body plan. The four pairs of comb rows are largely derived from the four E blastomeres. The aboral micromeres give rise to the entire ectodermal-derived tissues (epidermis, apical organ, pharynx, nerve net, ctene plates, and tentacle sheath), the internal macromeres give rise to the endoderm (gut, endodermal canal system, anal canals, and photocytes), 
and the eight oral micromeres give rise the 'mesoderm' (the entire musculature and mesenchymal cells).

\section{Antibody Specificity}

Rabbit polyclonal affinity-purified antibodies against unique peptide regions of M. leidyi ßcatenin (Bethyl Laboratories, Inc.) and Dishevelled were used to determine their spatial and temporal expression at different developmental stages. Each antibody was characterized by Western blotting to establish its specificity (Figure S1). Western blots of M. leidyi adult extracts showed that the antibodies recognized different bands (Figure S1) for Mlß-catenin (predicted size 99.5 KD; Figure S1A) and $M l D v 1$ (predicted size 68.9 KD; Figure S1A). Pre-adsorption of the $M l B$-catenin antibody with a tenfold molar excess of the antigenic peptide (used to generate and affinity purify the antibodies) resulted in the elimination of the appropriate-sized single band for $M l B$-catenin (Figure S1A). MlDvl antibody detected a single band around $100 \mathrm{KD}$ (Figure S1A), suggesting a high phosphorylation state as in other systems $(12,13)$. In addition, whole-mount immunohistochemistry pre-adsorption experiments were performed to test the specificity of the $M l \beta-$ catenin antibody by whole-mount immunohistochemistry. The staining pattern was strongly, but not completely, attenuated in early embryos when pre-incubated antibodies were used (Figure S1B).

MlDvl is differentially localized during $M$. leidyi embryogenesis and resembles the localization of $\underline{\mathrm{n} M l ß-\text { catenin during gastrulation }}$

Dishevelled is a protein that is normally associated with Wnt receptors and is actively involved in $\beta$-catenin activation. To observe the localization of $M l D v l$ protein, whose gene expression is detectable from the beginning of development (14), we used a specific MlDvl antibody. $M l D v l$ was observed to be homogenously distributed in the cortex of M. leidyi eggs as punctate aggregates (Figure S5). No clear asymmetric localization was detected until the formation of the first cell division where $M l \mathrm{Dv} l$ localizes to the animal pole at the cortex surrounding the first and second cleavage furrows (Figure S5). This data suggest that fertilization may trigger the segregation of $M l \mathrm{Dv} l$ to the future animal pole. Later, at the eight-cell stage, $M l \mathrm{Dv} l$ localizes to the vegetal pole at the cortex surrounding the third cleavage furrows (Figure S5). However, no asymmetric localization of $M l \mathrm{Dv} l$ was clearly detectable in the following stages up to gastrulation. 
Similar to $M l ß$-catenin, $M l \mathrm{Dvl}$ is detectable through the cytoplasm of all embryonic cells between 3$4 \mathrm{hpf}$ (Figure S6) and displays a nuclear localization $(15,10)$ in prospective endodermal cells. During the epiboly of the micromeres (3-4 hpf), MlDvl localizes to the cortex of the vegetal cells forming a ring-like structure (Figure S6). Between 4-5 hpf, $M l \mathrm{Dvl}$ localizes to the cortex and nuclei of the 'mesodermal' cells in close proximity with the vegetal micromeres, and in the nuclei of endodermal cells (Figure S6). Furthermore, at this stage, $M l$ Dvl distributes with the dividing chromosomes of 4-8 rows of vegetal micromeres perpendicular to the tentacular plane (nMlß-catenin (Figure 3A) is present in cells between these rows), and with the dividing chromosomes of 8-16 animal micromeres parallel to the tentacular plane (Figure S6). This distribution pattern suggests a tissue specific regulation of $M l D v l$ that may have roles in cell specification $(13,15-17)$.

From 5 to $7 \mathrm{hpf}$ (Figure S6), MlDvl is nuclear at the endodermal and 'mesodermal' cells, as well as, in the animal (prospective pharynx) and vegetal ectoderm (prospective apical organ). Between 8-9 hpf, $M l \mathrm{Dv} l$ is differentially localized in the M. leidyi embryo (Figure S6). MlDvl is cortically localized in ectodermal cells surrounding the prospective pharynx (oral) and in ectodermal cells of the developing apical organ and tentacular sheaths (aboral). While its specific subcellular localization is not clear in cells of the oral ectoderm, $M l \mathrm{Dv} l$ asymmetrically localizes to the basal cortex of the cells at the aboral ectoderm (Figure S6). MlDvl is also asymmetrically localized to the basal cortex of endo- and mesodermally derived cells in contact with the overlying aboral ectoderm, suggesting an activation of the Wnt signaling pathway in these tissues (14). In addition, MlDvl displays nuclear localization in cells of the prospective pharynx, the prospective apical organ, and internal tissues derived from endo- and 'mesodermal' cells. After 10-hpf, the cortical localization of $M l \mathrm{Dv}$ is no longer observable and its nuclear localization is barely detected in few tissues: aboral end of the pharynx, tentacles apparatus, and apical organ (Figure S6). Interestingly, MlDvl is not present in the comb plates cells (Figure S6).

\section{CRRISPR/Cas9 KOs}

We characterized the phenotype of CRRISPR/Cas9 KOs embryos at the cydippid stage. We repeated the experiment five times, obtaining similar phenotypes with a similar penetrance each time (proportion: 8/20 embryos injected each time). 'Mutant' embryos lack all of their internal endodermal and 'mesodermally' derived tissues (Figure S7). On the other hand, ectodermally derived epidermal and tentacular sheaths, comb plates, pharynx, and apical organ (dome cilia) 
developed normally. This is surprising if we consider our previous observations where $n M l ß$-catenin is present in cells of all three germ layers (Figures 3 and S3). At this stage, we could successfully obtain preliminary phenotypes using CRRISPR/Cas9 knock-outs of $M l \beta$-catenin gene. However, due to the difficulties presented in manipulating ctenophore eggs, we were not able to confirm these results in a large scale to genotype the mutations and further work and technology development is required.

\section{Supplementary Discussion.}

Maternal Wnt/ß-catenin signaling pathway and cell-fate specification

The regulation of the Wnt/ß-catenin signaling pathway plays a key role in cell-specification during the embryonic development of studied animals. Because we do not have specific antibodies to other Wnt related proteins, we do not yet know whether the proteins of these genes are maternally loaded into the egg, but our data suggest that the Wnt/ß-catenin pathway is activated during early stages by maternally loaded $M l B$-catenin and $M l D v l$ proteins (Figures 2 and S5). Our immunostaining results shows that $\mathrm{n} M l ß$-catenin is localized in both oral macromeres and $\mathrm{E}$ blastomere-descendant micromeres but not in m-M blastomere descendant micromeres at the 16-cell stage (Figures 2 and S2) and during epiboly before gastrulation at 3 hpf (Figures S3A). Previous studies have shown that even though the normal development of M. leidyi is affected by drugmodifications of cell division patterns and protein translation during early stages, the cell-fate of some tissues (e.g., comb plates and apical organ) remains unaffected in drug-treated embryos (8). These observations, along with $L v$-cadherin experiments and preliminary CRISPR/Cas9 phenotypes, suggest that $\mathrm{n} M l ß$-catenin has maternal roles specifying early cell-fates lineages.

Furthermore, transcriptomic data (18) and the asymmetric localization of $M l \mathrm{Dvl}$ to the animal cortex and cleavage furrow of early zygotes (Figure S5) suggest that the Wnt/ß-catenin signaling gets activated around the time of fertilization. This is interesting because ctenophores fertilization is uniquely characterized by the migration of the egg pronucleus that 'chooses' a single sperm pronucleus out of many pronuclei scattered around the cortical cytoplasm (10). The migration of the egg pronucleus is mediated by astral microtubules network generated by the sperm $(19,20)$, and once both pronucleus fuse, the first cell division determine the animal-vegetal axis $(9,10,19)$. It could be possible that sperm entry differentially localizes $M l \mathrm{Dvl}$ and other proteins by cytoskeleton rearrangements in the egg cortex, and the egg pronucleus (containing $\mathrm{n} M l \beta$-catenin) moves towards the future animal pole where $M l \mathrm{Dvl}$ is localized at higher concentrations. However, further 
improvements in are required to elucidate this and other hypotheses about the role and interactions of maternal Wnt signaling pathway and the establishment of the animal-vegetal (oral-aboral) axis. We need better methods to observe the dynamic and function of these proteins during early stages of development. Ctenophore development is highly stereotyped, and cell-fates of some adult tissues (e.g., comb rows and apical organ) are already determined at the first cleavage cycles $(8,21,22)$. It has been suggested that a "cleavage clock" regulates early cell-fate segregation and determination (8), in this context, it might be that the Wnt/B-catenin signaling dynamics observed here are markers of this cell cycle timing. Therefore, we should not only study the molecular composition but also the cell behavior of blastomere cell-linages to understand the interactions underlying the regulation of $M l ß-c a t e n i n$ and cell-specification.

\section{Zygotic Wnt/ß-catenin Signaling Pathway and Gastrulation Movements}

Transcriptomic data suggest that all four M. leidyi Wnt genes are expressed during early stages (18). However, previous results show that these genes are only detectable by in situ hybridization in the vegetal pole after the completion of gastrulation (5-6 hpf) when 'mesodermal' and endodermal cells have already internalized (14). This suggest that there is a transition between maternal and zygotic Wnts transcripts that may influence their subsequent function. Furthermore, in situ hybridization results also show that, with the exception of $M l \mathrm{FzdA}$ and $M l \mathrm{Dvl}$, transcripts for most of the components of the Wnt signaling pathway express after (e.g., $M l \mathrm{FzdB}, M l \mathrm{Sfrp}$, and $M l \mathrm{Tcf}$ ) or during (e.g., Mlß-catenin) later stages of gastrulation (14). Thus, their zygotic proteins are not involved in early embryonic patterning but may have roles in later morphogenesis or cell specification events (e.g., endodermal canals, gut, and musculatures).

As with bilaterian embryos (23-28), M. leidyi Wnt proteins may act as morphogens that lead the gastrulation movements of 'mesodermal' cells towards the vegetal pole where $M l \mathrm{Dvl}$ may bind with $M l$ Fzd at the cortex, allowing the nuclearization of $M l ß$-catenin in proximal cells. The cortical localization of $M l \mathrm{Dv}$ at the vegetal pole during gastrulation (Figure S6), the cortical localization of $M l \mathrm{Dvl}$ in 'mesodermal' cells adjacent to the vegetal Wnt expressing ectoderm (Figure S5; $4 \mathrm{hph}$ ), and the expansion of $M l B$-catenin nuclearization after 'mesodermal' cells contact the vegetal pole (Figure 3; $5 \mathrm{hpf}$ ) suggest that zygotic Wnt ligand proteins are present in vegetal cells at this stage of development (14). In addition, our experiments overexpressing $L v$-cadherin (Figure 4 ), and preliminary CRISPR/Cas9 results (Figure S7), suggest a conserved role of zygotic Wnt/B-catenin 
signaling pathway in mesendodermal precursors and that zygotic $M l ß$-catenin has a conserved role in tissue specification in later stages.

Intriguingly, our results show transient waves of $M l \beta$-catenin nuclearization in all cells of the embryo (Figure S3). These observations suggest transient and stage-specific waves of either Wnt signaling pathway activation or inactivation. This is consistent with the redeployment of Wnt signaling pathways in other systems. For example, in N. vectensis there is an early nuclearization of B-catenin that specifies endomesoderm $(12,29)$, but at gastrulation Wnt signaling is activated at the blastopore to pattern the entire oral-aboral axis (30-32).

The discrete gene expression of Wnt ligands in regions associated with the aboral/vegetal pole, tentacle apparati, and apical organ (14), is concordant with $\mathrm{n} M l \beta$-catenin (Figures 3, S3) and $M l \mathrm{Dv} 1$ (Figure S6) proteins localization in post-gastrulation stages. However, such gene expression patterns do not explain the activation of the Wnt signaling pathway when $\mathrm{n} M l \beta$-catenin is observed in all cells of the embryo. One option is that the morphogen activity of Wnt ligands induces the activation of the signaling pathway in neighboring cells (23-28). In this scenario, the inactivation of this pathway should act as a regulator of $\mathrm{n} M l \beta$-catenin (Figure S8), most likely, in a dose-dependent manner $(33,34)$. Unless unknown factors inhibit the $M$. leidyi Wnt/ß-catenin signaling pathway, the genomic absence of cadherin-catenin binding domains (35), Wnt/PCP components, Wnt antagonists (DKK, WIF, and CER), and the netrin related domain of $M l$ Sfrp $(14,36)$ suggest that this inhibition may happen downstream of $M l \mathrm{Fzd}$. However, it could also be possible that the activation of Wnt/ßcatenin signaling pathway is regulated by a differential expression of TCF and or GSK-3ß (37-40). We need to develop more specific antibodies and recombinant proteins to these key players in order to elucidate the role of the Wnt pathway in M. leidyi development.

At this point, we cannot discard the unlikely possibility that $M l ß$-catenin has no functional role in $M$. leidyi development and its nuclear localization is a consequence of its conserved protein structure $(14,35,41)$. Hence, we can now only say that $M l ß$-catenin protein is differentially localized during M. leidyi development and can be used as a molecular marker to identify different rounds of celltissue specification, including the segregation of the three distinct germinal layers. 


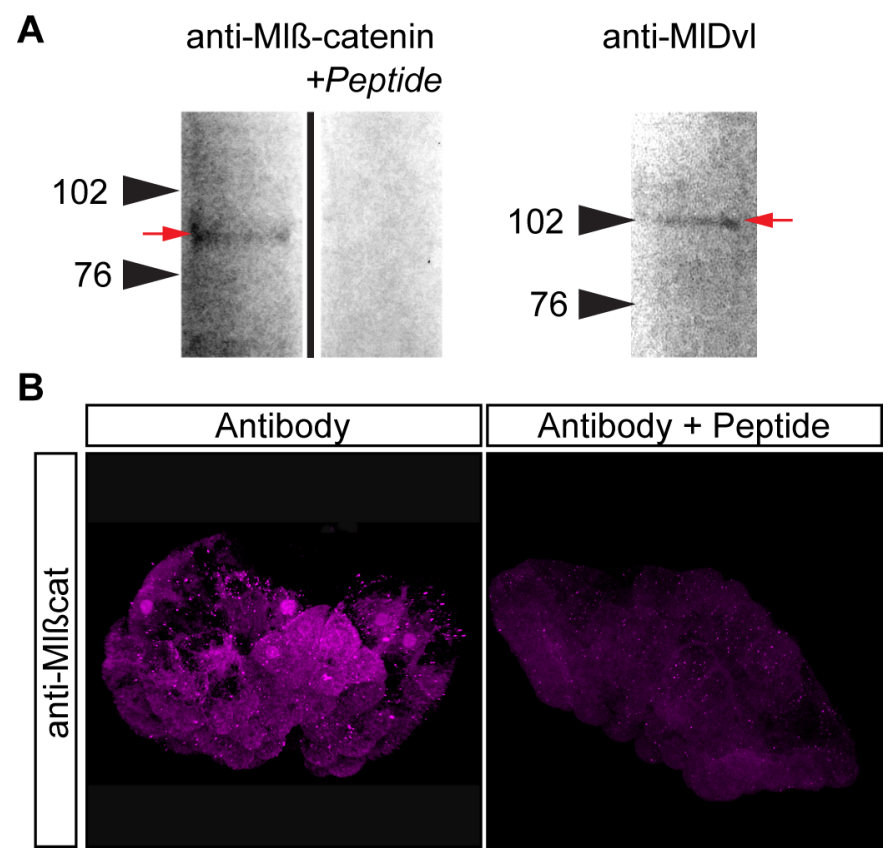

Figure S1. M. leidyi antibodies tested by western blots and pre-adsorption experiments. A)

Western blots of $M$. leidyi adult tissue extracts using specific antibodies against $M l ß$-catenin and $M l$ Dvl. Pre-adsorption of the antibodies with a tenfold excess of the antigen peptide resulted in the elimination of the staining of a single band for $M l \beta$-catenin. Arrowheads indicate the molecular weight in KD. A red arrow indicates the band recognized by the antibody for each protein. B) Whole-mount immunohistochemistry pre-adsorption experiments show that the staining pattern was strongly mitigated in early embryos when pre-incubated antibody against $M l ß$-catenin with the respective peptide.

\section{Figure S2. Mlß-catenin protein localizes in the nucleus of the eggs and in every blastomere}

until the 16-cell stage. A) Immunostaining against $M l ß$-catenin during cleavage stages of $M$. leidyi development. Nuclear $M l ß$-catenin (white arrows) was not detected in the middle vegetal micromeres (yellow arrowheads) at 16-cell and 32-cell stages. Images are 3D reconstructions from a z-stack confocal series. Single optical sections are indicated. Orientation axes are depicted in the figure. B) A single optical section from the 16-cell stage z-stack confocal series shown in A. Mlßcatenin protein localizes to the nucleus of el micromeres white arrows) but is absent from $\mathrm{m} 1$ macromeres nuclei (yellow arrowheads). C) Diagram depicting the nuclear localization of $M l ß-$ catenin. Animal pole is to the top as depicted in A. Morphology is shown by DAPI and Tubulin immunostainings. Homogeneous cytosolic staining was digitally reduced. 
bioRxiv preprint doi: https://doi.org/10.1101/520957; this version posted January 17,2019 . The copyright holder for this preprint (which was not certified by peer review) is the author/funder, who has granted bioRxiv a license to display the preprint in perpetuity. It is made available under aCC-BY-NC-ND 4.0 International license.
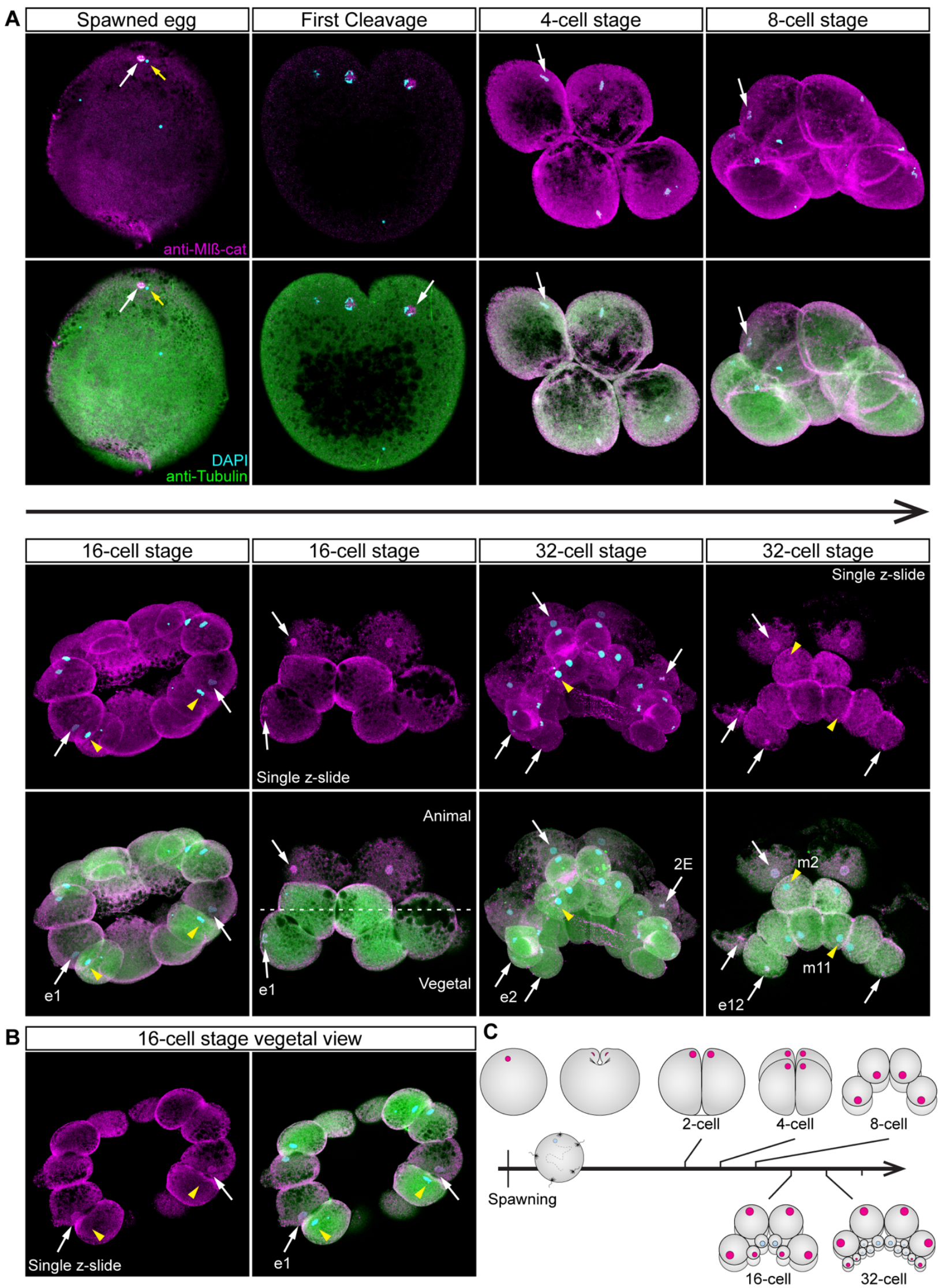


\section{Figure S3. Mlß-catenin protein dynamics during and after M. leidyi gastrulation. A)}

Immunostaining against $M l ß$-catenin during early gastrulation stages of $M$. leidyi development. $M l ß-$ catenin protein localizes in the nuclei of prospective endodermal cells (white arrowheads). Mlßcatenin protein is nuclear in the animal ectoderm at $3 \mathrm{hpf}$ and in subset of vegetal ectodermal cells at 4 hpf (White arrows). B) Immunostaining against $M l \beta$-catenin during late gastrulation stages of $M$. leidyi development. $M l ß$-catenin protein transiently localizes in the nuclei of every cell at $5 \mathrm{hpf}$; white arrows indicate ectodermal cells. Between 5-6 hpf, $M l ß$-catenin remains cytosolic in all cells. Between 6-7 hpf, nuclear $M l ß$-catenin is only observable in endodermal (white arrowheads) and 'mesodermal' cells (yellow arrows). Orientation axes and germ layers are depicted in the figure: Animal/Oral pole is to the top. Ecto: Ectoderm. Endo: Endoderm. 'Meso': 'mesoderm.' A.O.: prospective Apical Organ. '*': prospective comb plates. C) Immunostaining against $M l ß$-catenin after gastrulation stages of $M$. leidyi development. $M l \beta$-catenin protein transiently localizes in the nuclei of every cell at $8 \mathrm{hpf}$ but it regionalizes after $9 \mathrm{hpf}$. $M l \beta$-catenin protein localizes in the nuclei of epidermal ectodermal cells (White arrows), pharyngeal cells (yellow arrowhead) endodermal cells (white arrowheads), and 'mesodermal' cells (yellow arrow). Orientation axes are depicted in the figure. phx: pharynx. Ts: Tentacle sheath. Ta: Tentacle apparatus. c.p.: comb plates. '?': unknown tissue. No cortical localization was observed at the cell-contact region. Images are 3D reconstructions from a z-stack confocal series. Homogeneous cytosolic staining was digitally reduced. Morphology is shown by DAPI and Tubulin immunostainings. 
bioRxiv preprint doi: https://doi.org/10.1101/520957; this version posted January 17,2019 . The copyright holder for this preprint (which was not certified by peer review) is the author/funder, who has granted bioRxiv a license to display the preprint in perpetuity. It is made available under aCC-BY-NC-ND 4.0 International license.
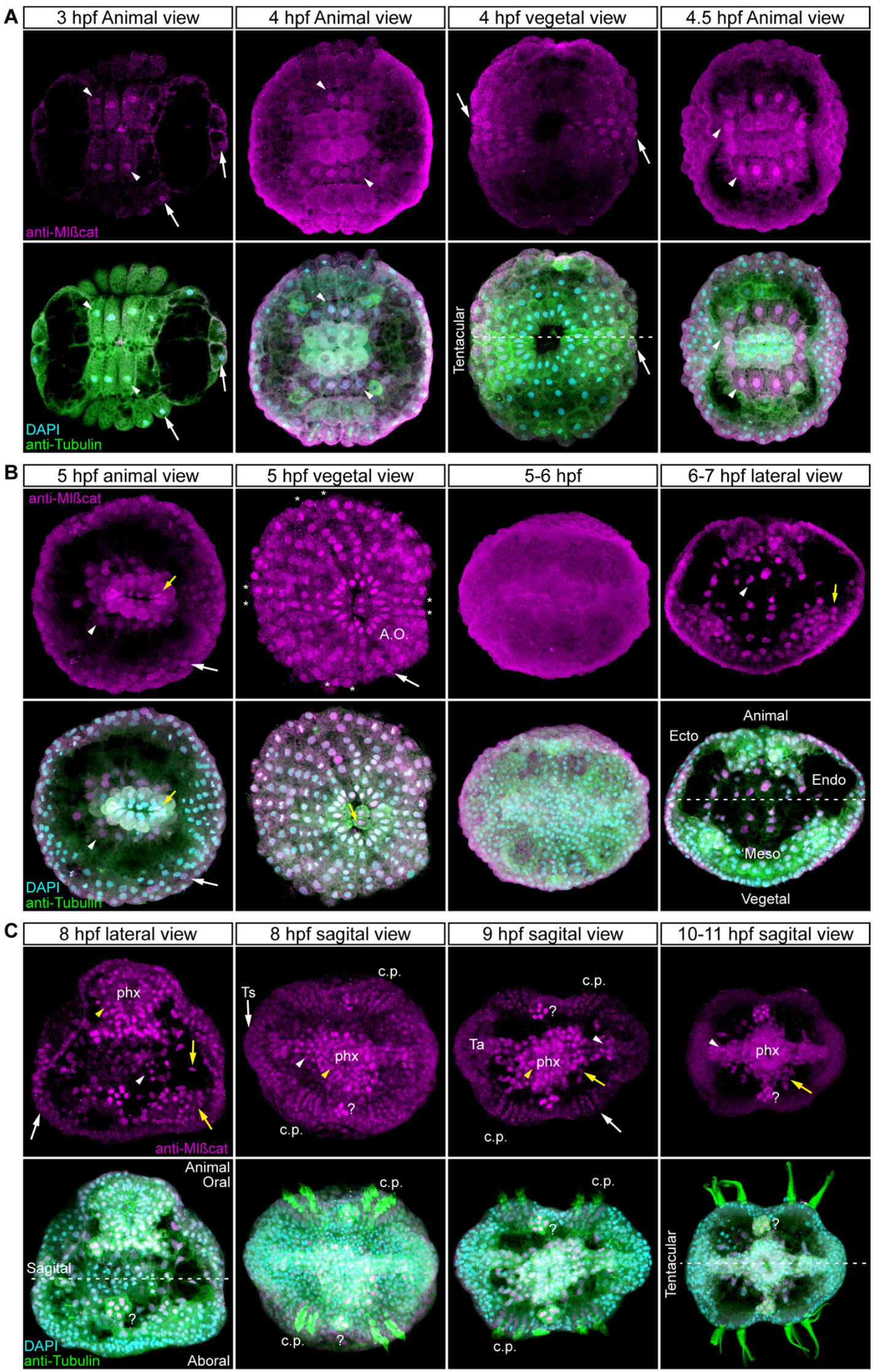

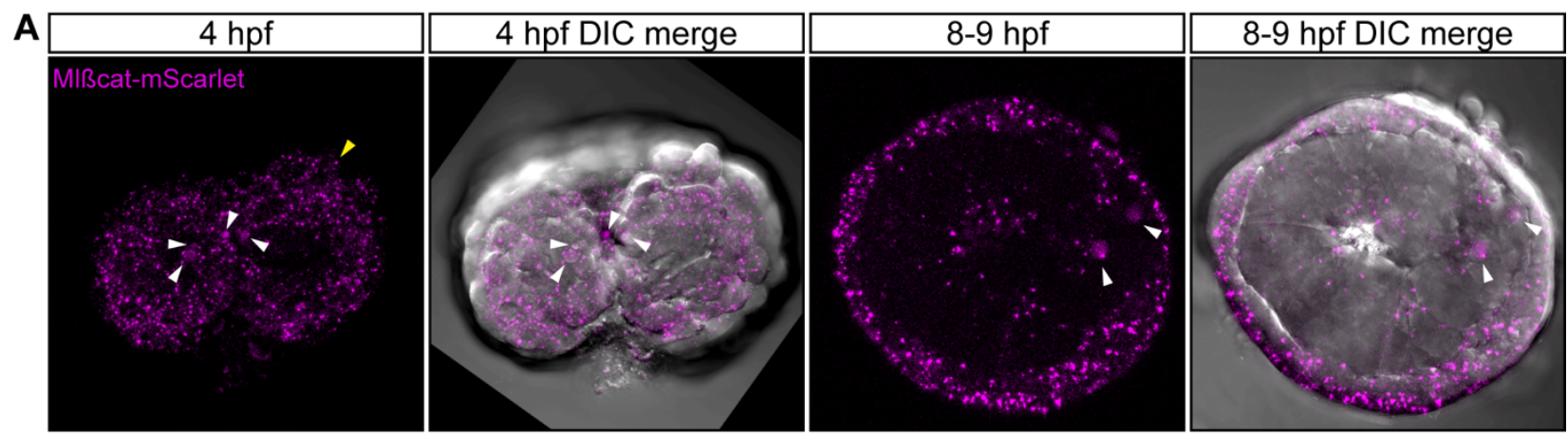

Figure S4. In vivo localization of $M l \beta$-catenin-mScarlet during different stages of $M$. leidyi

development. The overexpression of $M l ß$-catenin-mScarlet protein displays similar patterns observed with the antibody staining against the same protein at $4 \mathrm{hpf}$, and no cortical localization was observed. However, we were not able to dissociate nuclear $M l ß$-catenin-mScarlet from its cytosolic localization by this method at later stages. All images are 3D reconstructions from a zstack confocal series. Morphology is shown by DIC microscopy. White arrowheads indicate Mlßcatenin-mScarlet protein nuclear localization. Yellow arrowhead indicates $M l \beta$-catenin-mScarlet protein cytosolic aggregates. Movie S3 shows the in vivo expression of Nvß-catenin::GFP into $M$. leidyi embryos that resembles antibody staining. 

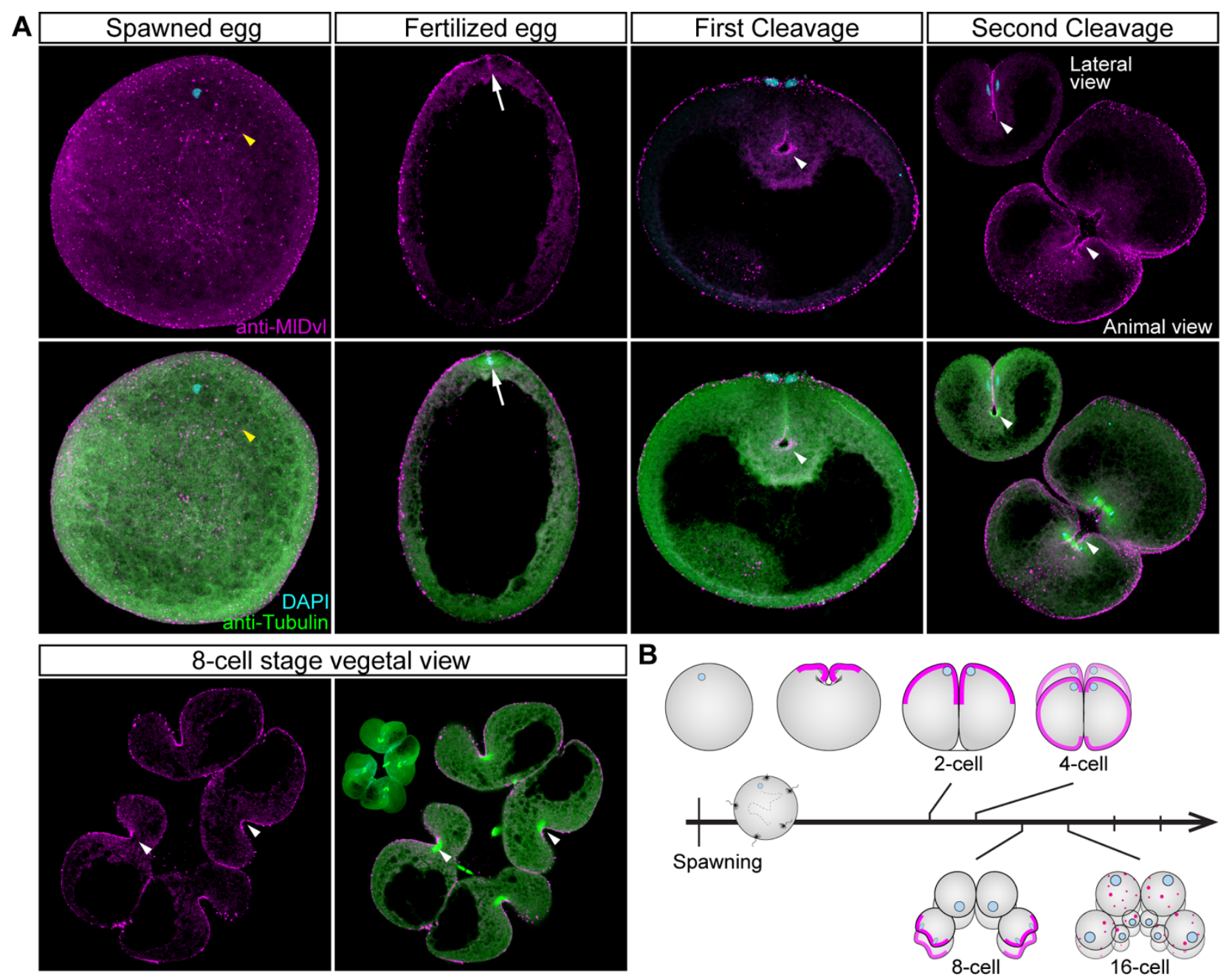

Figure S5. MIDvl protein localizes in the cortex surrounding the cleavage furrows. A)

Immunostaining against $M l \mathrm{Dv} l$ during cleavage stages of $M$. leidyi development. In the eggs, $M l \mathrm{Dv} l$ protein distributes as punctate aggregates (yellow arrowhead). Cortical and asymmetric $M l D v l$ protein (white arrow) was not detected until the first cell division. Orientation axes are depicted in the figure. Animal and lateral (upper left) views of two different embryos are shown in the second cleavage panels. Images are 3D reconstructions from a z-stack confocal series except for 8 cellstage. 8-cell stage images are a single optical section from a z-stack confocal series (3D reconstruction is shown in the upper left corner for orientation purposes). White arrowheads indicate cortical $M l \mathrm{Dv} l$ at the cleavage furrows B) Diagram depicting the cortical localization of $M l \mathrm{Dv} l$ (magenta). Animal pole is to the top. Morphology is shown by DAPI and Tubulin immunostainings. Homogeneous cytosolic staining was digitally reduced. See Figure S5 for later stages. 


\section{Figure S6. $M I D v l$ resembles the localization of $\mathbf{n} M I l \beta$-catenin during gastrulation. A)}

Immunostaining against $M l \mathrm{Dv}$ during and after gastrulation stages of $M$. leidyi development. $M l \mathrm{Dvl}$ protein localizes in the nuclei of prospective endodermal cells (white arrowheads) and ectodermal cells (white arrows). MlDvl protein distributes with the dividing chromosomes ('*') in the animal ectoderm and in subset of vegetal ectodermal cells at $4 \mathrm{hpf}$. MlDvl protein localizes to the cortex of the 'vegetal-ring' cells (yellow arrowheads). MlDvl localization in 'mesodermal' cells is indicated by yellow arrows. No cortical localization was observed at the cell-contact region. Images are 3D reconstructions from a z-stack confocal series. Orientation axes and germ layers are depicted in the figure. Ecto: Ectoderm. Endo: Endoderm. 'Meso': 'mesoderm.' phx: pharynx. Ts: Tentacle sheath. Ta: Tentacle apparatus. c.p.: comb plates. '?': unknown tissue. ‘*' at 3-4 hpf: MlDvl chromosomal localization. '*' after $7 \mathrm{hpf}$ : $M l \mathrm{D}$ vl cortical localization. B) Diagram depicting the $M l$ Dvl protein localization during and after gastrulation. Upper row: lateral view. Lower row: aboral view. Morphology is shown by DAPI and Tubulin immunostainings. 
bioRxiv preprint doi: https://doi.org/10.1101/520957; this version posted January 17, 2019. The copyright holder for this preprint (which was not certified by peer review) is the author/funder, who has granted bioRxiv a license to display the preprint in perpetuity. It is made available under aCC-BY-NC-ND 4.0 International license.

A
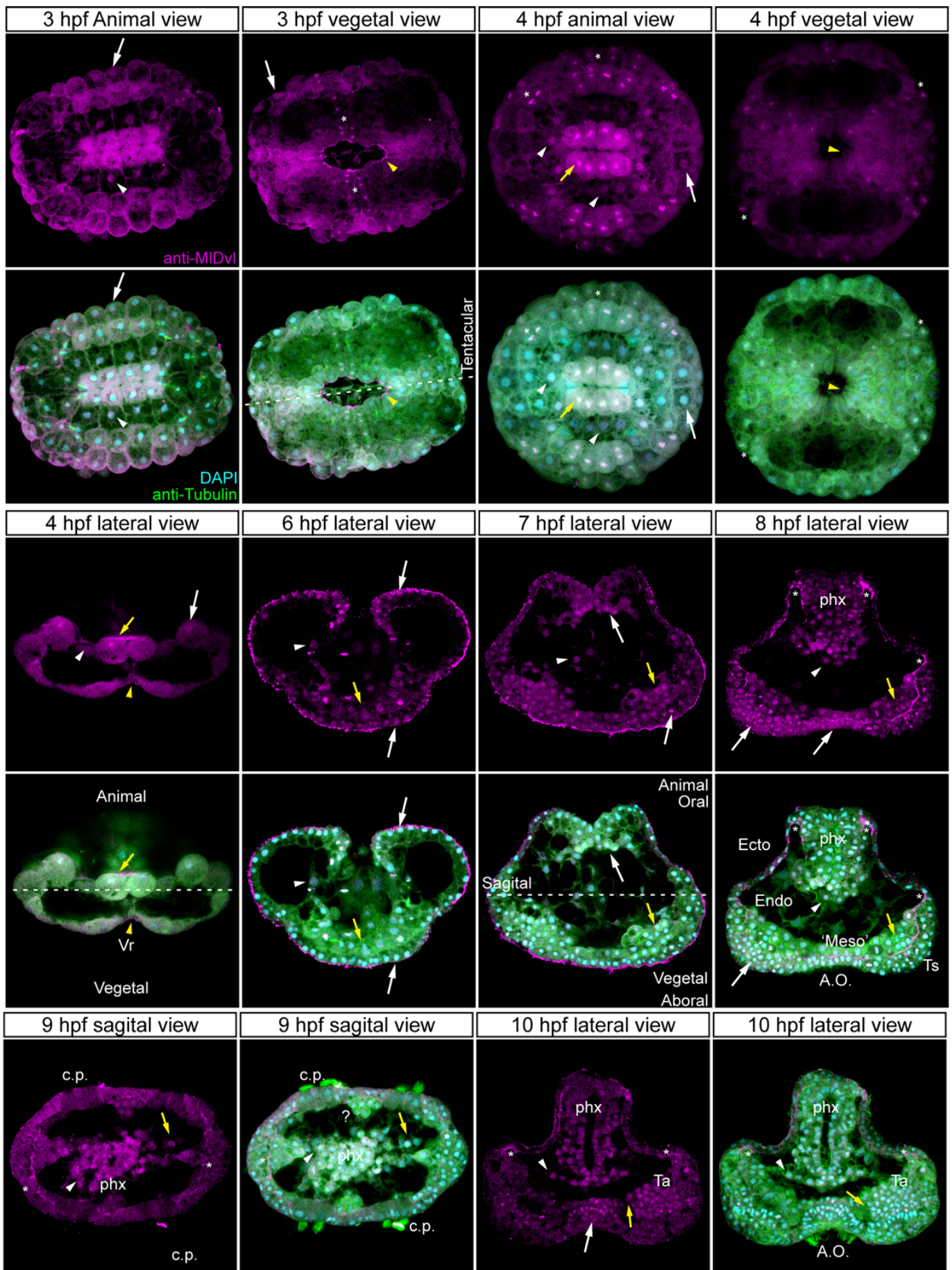

Endoderm 'Mesoderm' MIDv

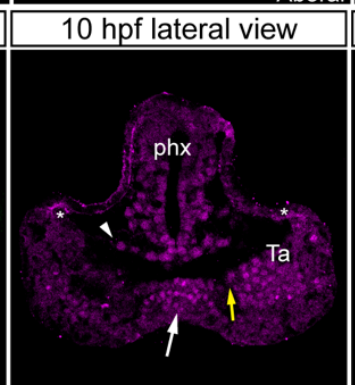

\section{$10 \mathrm{hpf}$ lateral view}
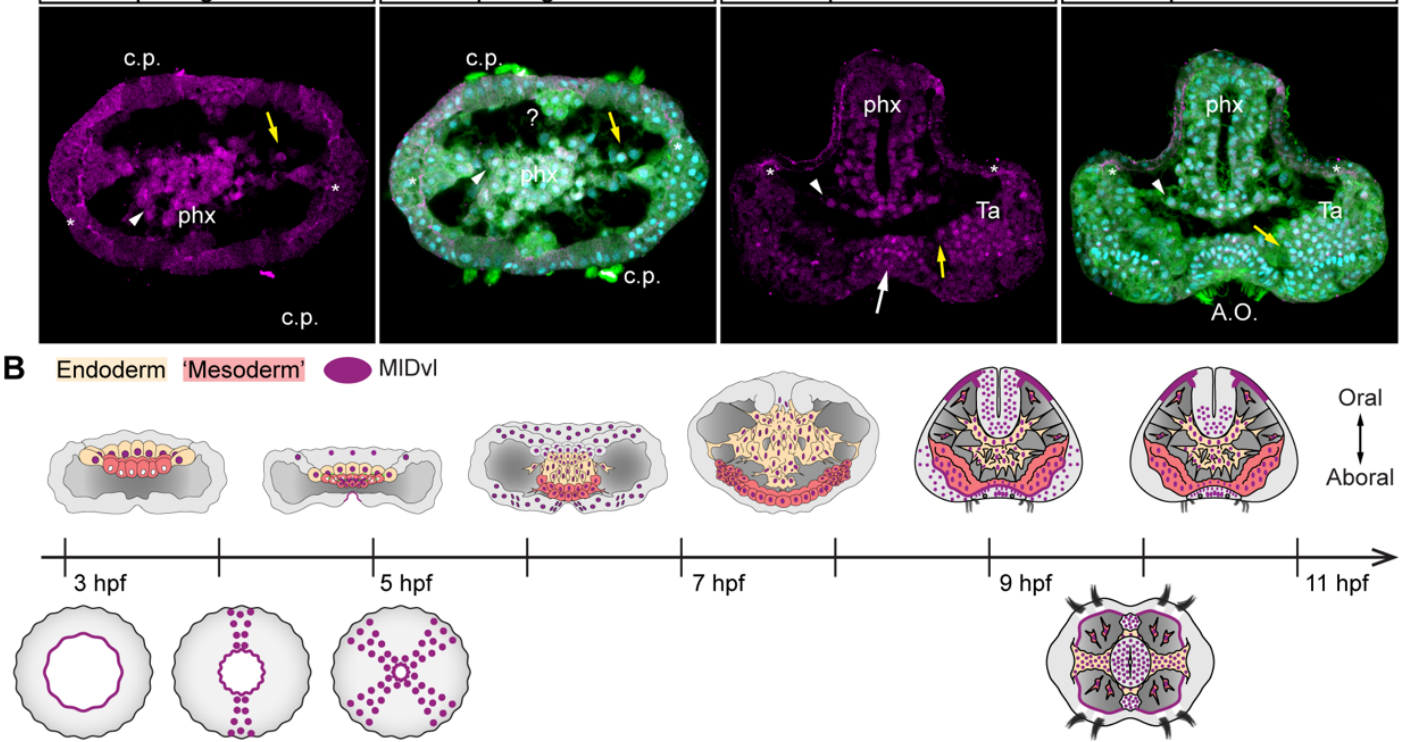

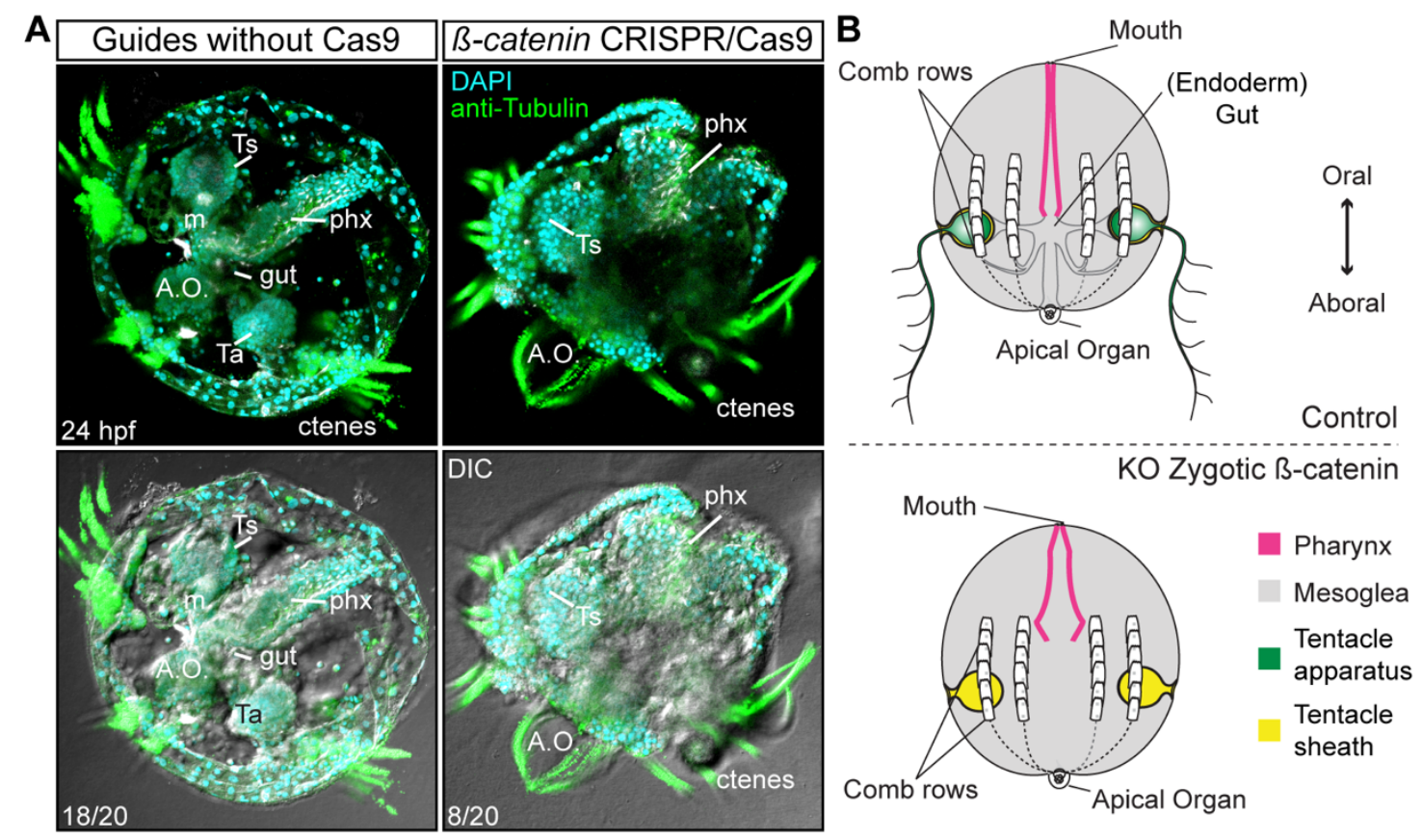

Figure S7. CRRISPR/Cas9 knock-outs of Mlß-catenin gene. A) Mutant embryos lacked internal tissues including musculature ('m') and gut but developed ectodermal structures such as comb plates (ctenes), apical organ (A.O.), ectodermal pharynx (phx), and epidermal tissue as is depicted in B. Ts: Tentacle sheath. Morphology is shown by DAPI and Tubulin immunostainings. 


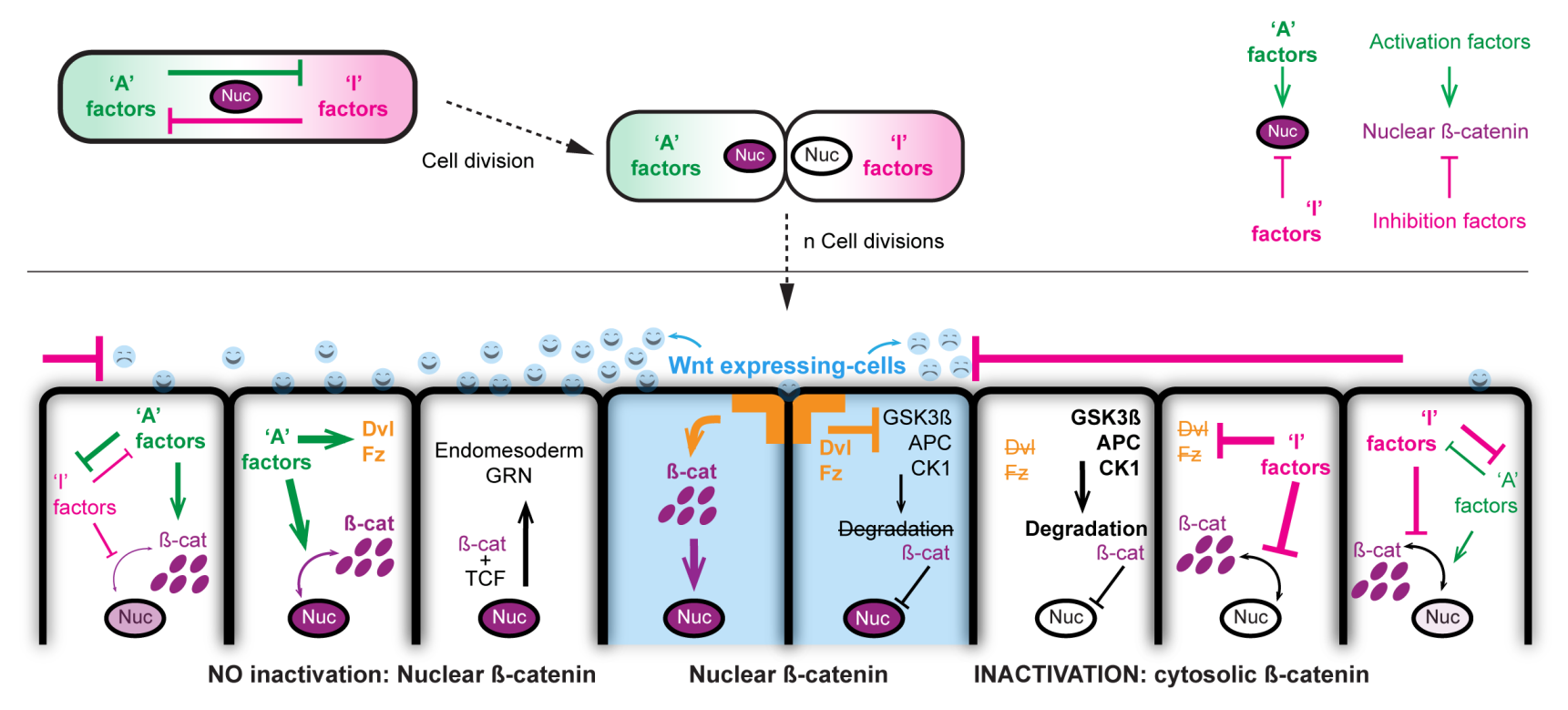

Figure S8. The morphogen activity of Wnt ligands during the early development of M. leidyi.

Diagram depicting our hypothesis on the regulation of Wnt signaling and nuclear B-catenin by the inactivation of this pathway in neighboring cells. M. leidyi cell-fate determinants are already polarized in the egg and partitioned since the first cell division. Several rounds of cell divisions distribute molecular factors that activate and or inhibit the Wnt signaling, leading to a differential nuclearization of $M l ß$-catenin.

Movie S1. Z-stack series of Immunostaining against $M l ß$-catenin during late gastrulation stages of M. leidyi development. Mlß-catenin protein transiently localizes in the nuclei of every cell at $5 \mathrm{hpf}$.

Movie S2. Z-stack series of in vivo Histone::RFP microinjected into the uncleaved eggs.

Histone::RFP protein localizes in the nuclei of every cell at $24 \mathrm{hpf}$ without altering the normal development of M. leidyi embryos.

Movie S3. Z-stack series of in vivo Nvß-catenin::GFP microinjected into the uncleaved eggs. Nvßcatenin::GFP protein resembles M1ß-catenin antibody staining. 
bioRxiv preprint doi: https:/doi org/10.1101/520957: this version posted January 17,2019 The copyright holder for this preprint (which was not certified by peer review) is the author/funder, who has granted bioRxiv a license to display the preprint in perpetuity. It is made available under aCC-BY-NC-ND 4.0 International license. 


\section{SUPPLEMENTARY REFERENCES}

1. M. Salinas-Saavedra, M. Q. Martindale, Improved protocol for spawning and immunostaining embryos and juvenile stages of the ctenophore Mnemiopsis leidyi. Protoc. Exch. (2018), doi:10.1038/protex.2018.092.

2. M. Salinas-Saavedra, T. Q. Stephenson, C. W. Dunn, M. Q. Martindale, Par system components are asymmetrically localized in ectodermal epithelia, but not during early development in the sea anemone Nematostella vectensis. Evodevo. 6 (2015), doi:10.1186/s13227-015-0014-6.

3. M. Salinas-Saavedra, A. Q. Rock, M. Q. Martindale, Germ layer-specific regulation of cell polarity and adhesion gives insight into the evolution of mesoderm. Elife. 7 (2018), doi:10.7554/eLife.36740.

4. M. J. Layden, E. Röttinger, F. S. Wolenski, T. D. Gilmore, M. Q. Martindale, Microinjection of mRNA or morpholinos for reverse genetic analysis in the starlet sea anemone, Nematostella vectensis. Nat. Protoc. 8, 924-934 (2013).

5. J. G. Doench et al., Rational design of highly active sgRNAs for CRISPRCas9\&amp;ndash;mediated gene inactivation. Nat. Biotechnol., 1-8 (2014).

6. M. A. Moreno-Mateos et al., CRISPRscan: designing highly efficient sgRNAs for CRISPRCas9 targeting in vivo. Nat. Methods. 12, 982-988 (2015).

7. M. Q. Martindale, J. Q. Henry, Intracellular fate mapping in a basal metazoan, the ctenophore Mnemiopsis leidyi, reveals the origins of mesoderm and the existence of indeterminate cell lineages. Dev. Biol. 214, 243-257 (1999).

8. A. H. L. Fischer, K. Pang, J. Q. Henry, M. Q. Martindale, A cleavage clock regulates features of lineage-specific differentiation in the development of a basal branching metazoan, the ctenophore Mnemiopsis leidyi. Evodevo. 5, 0-19 (2014).

9. G. Freeman, The establishment of the oral-aboral axis in the ctenophore embryo. Development. 42, 237-260 (1977).

10. D. Carré, C. Rouvière, C. Sardet, In vitro fertilization in ctenophores: sperm entry, mitosis, and the establishment of bilateral symmetry in Beroe ovata. Dev. Biol. 147, 381-391 (1991).

11. G. Freeman, The role of cleavage in the localization of developmental potential in the ctenophore Mnemiopsis leidyi. Dev. Biol. 49, 143-177 (1976).

12. P. N. Lee, S. Kumburegama, H. Q. Marlow, M. Q. Martindale, A. H. Wikramanayake, Asymmetric developmental potential along the animal-vegetal axis in the anthozoan 
cnidarian, Nematostella vectensis, is mediated by Dishevelled. Dev. Biol. 310, 169-186 (2007).

13. C. J. Peng, A. H. Wikramanayake, Differential Regulation of Disheveled in a Novel Vegetal Cortical Domain in Sea Urchin Eggs and Embryos: Implications for the Localized Activation of Canonical Wnt Signaling. PLoS One. 8, e80693-15 (2013).

14. K. Pang et al., Genomic insights into Wnt signaling in an early diverging metazoan, the ctenophore Mnemiopsis leidyi. Evodevo. 1, 10 (2010).

15. K. Itoh, B. K. Brott, G.-U. Bae, M. J. Ratcliffe, S. Y. Sokol, Nuclear localization is required for Dishevelled function in Wnt/ß-catenin signaling. J. Biol. 4, 3 (2005).

16. Y. Lee et al., Dishevelled has a YAP nuclear export function in a tumor suppressor contextdependent manner. Nat. Commun. 9, 2301 (2018).

17. C. C. Malbon, H. Wang, (Academic Press, 2005), vol. 72 of Current Topics in Developmental Biology, pp. 153-166.

18. L. S. Babonis et al., Integrating embryonic development and evolutionary history to characterize tentacle-specific cell types in a ctenophore. Mol. Biol. Evol., msy171 (2018).

19. E. Houliston, D. Carré, J. A. Johnston, C. Sardet, Axis establishment and microtubulemediated waves prior to first cleavage in Beroe ovata. Development. 117, 75-87 (1993).

20. E. Houliston, D. Carré, P. Chang, C. Sardet, Cytoskeleton and ctenophore development. Curr. Top. Dev. Biol. 31, 41-63 (1995).

21. M. Q. Martindale, J. Q. Henry, Reassessing embryogenesis in the Ctenophora: the inductive role of e1 micromeres in organizing ctene row formation in the \&apos;mosaic\&apos; embryo, Mnemiopsis leidyi. Development. 124, 1999-2006 (1997).

22. J. Q. Henry, M. Q. Martindale, Regulation and regeneration in the ctenophore Mnemiopsis leidyi. Dev. Biol. 227, 720-733 (2000).

23. C. Kimura-Yoshida et al., Canonical Wnt Signaling and Its Antagonist Regulate AnteriorPosterior Axis Polarization by Guiding Cell Migration in Mouse Visceral Endoderm. Dev. Cell. 9, 639-650 (2005).

24. Y. Zou, A. I. Lyuksyutova, Morphogens as conserved axon guidance cues. Curr. Opin. Neurobiol. 17, 22-28 (2007).

25. J. Heuberger, W. Birchmeier, Interplay of cadherin-mediated cell adhesion and canonical Wnt signaling. Cold Spring Harb. Perspect. Biol. 2, a002915 (2010).

26. L. Solnica-Krezel, D. S. Sepich, Gastrulation: making and shaping germ layers. Annu. Rev. 
Cell Dev. Biol. 28, 687-717 (2012).

27. O. Serralbo, C. Marcelle, Development, in press.

28. A. T. Baldwin, B. T. Phillips, in Perspectives in Translational Cell Biology, P. B. T.-C. P. in D. and D. Michael Conn, Ed. (Academic Press, Boston, 2018), pp. 61-102.

29. A. H. Wikramanayake et al., An ancient role for nuclear catenin in the evolution of axial polarity and germ layer segregation. Nature. 426, 446-450 (2003).

30. H. Q. Marlow, M. Srivastava, D. Q. Matus, D. Rokhsar, M. Q. Martindale, Anatomy and development of the nervous system of Nematostella vectensis, an anthozoan cnidarian. Dev. Neurobiol. 69, 235-254 (2009).

31. H. Marlow, D. Q. Matus, M. Q. Martindale, Ectopic activation of the canonical wnt signaling pathway affects ectodermal patterning along the primary axis during larval development in the anthozoan Nematostella vectensis. Dev. Biol. 380, 324-334 (2013).

32. L. Leclère, M. Bause, C. Sinigaglia, J. Steger, F. Rentzsch, Development of the aboral domain in Nematostella requires $\beta$-catenin and the opposing activities of Six3/6and Frizzled5/8. Development. 143, 1766-1777 (2016).

33. C. Y. Logan, J. R. Miller, M. J. Ferkowicz, D. R. McClay, Nuclear beta-catenin is required to specify vegetal cell fates in the sea urchin embryo. Development. 126, 345-357 (1999).

34. B. S. McCauley, E. Akyar, H. R. Saad, V. F. Hinman, Dose-dependent nuclear ß-catenin response segregates endomesoderm along the sea star primary axis. Development. 142, 207217 (2014).

35. H. Belahbib et al., New genomic data and analyses challenge the traditional vision of animal epithelium evolution. BMC Genomics. 19, 393 (2018).

36. J. F. Ryan et al., The Genome of the Ctenophore Mnemiopsis leidyi and Its Implications for Cell Type Evolution. Science (80-. ). 342, 1242592 (2013).

37. W. J. Nelson, R. Nusse, Convergence of Wnt, $\beta$-Catenin, and Cadherin pathways. Science (80-. ). 303, 1483-1487 (2004).

38. R. van Amerongen, R. Nusse, Towards an integrated view of Wnt signaling in development. Development. 136, 3205-3214 (2009).

39. E. Röttinger, P. Dahlin, M. Q. Martindale, A framework for the establishment of a cnidarian gene regulatory network for "endomesoderm" specification: the inputs of $\beta$-catenin/TCF signaling. PLoS Genet. 8, e1003164 (2012).

40. K. M. Loh, R. van Amerongen, R. Nusse, Generating Cellular Diversity and Spatial Form: 
bioRxiv preprint doi: https://doi.org/10.1101/520957; this version posted January 17,2019 . The copyright holder for this preprint (which was not certified by peer review) is the author/funder, who has granted bioRxiv a license to display the preprint in perpetuity. It is made available under aCC-BY-NC-ND 4.0 International license.

Wnt Signaling and the Evolution of Multicellular Animals. Dev. Cell. 38, 643-655 (2016).

41. S. Q. Schneider, J. R. Finnerty, Protein evolution: structure-function relationships of the oncogene beta-catenin in the evolution of multicellular animals. J. Exp. ... (2003), doi:10.1002/jez.b.00006. 
Table S1. Key resources table.

\begin{tabular}{|c|c|c|c|c|}
\hline $\begin{array}{l}\text { Reagent type } \\
\text { (species) or resource }\end{array}$ & Designation & Source or reference & Identifiers & $\begin{array}{l}\text { Additional } \\
\text { information }\end{array}$ \\
\hline Antibody & $\begin{array}{l}\text { Mouse Anti-alpha-Tubulin Monoclonal } \\
\text { Antibody, Unconjugated, Clone DM1A }\end{array}$ & Sigma-Aldrich & T9026; RRID:AB_477593 & $(1: 500)$ \\
\hline Antibody & $\begin{array}{l}\text { anti-MIß-catenin custom peptide } \\
\text { antibody produced in rabbit }\end{array}$ & Bethyl labs; This study & & $\begin{array}{l}\text { Stored at } \\
\text { MQ } \\
\text { Martindale's } \\
\text { lab; }(1: 100)\end{array}$ \\
\hline Antibody & $\begin{array}{l}\text { anti-MIDvl custom protein antibody } \\
\text { produced in rabbit }\end{array}$ & This study & & $\begin{array}{l}\text { Stored at } \\
\text { MQ } \\
\text { Martindale's } \\
\text { lab; }(1: 100)\end{array}$ \\
\hline Antibody & $\begin{array}{l}\text { Goat anti-Mouse IgG Secondary } \\
\text { Antibody, Alexa Fluor } 568\end{array}$ & Thermo Fisher Scientific & A-11004; RRID:AB_2534072 & $(1: 250)$ \\
\hline Antibody & $\begin{array}{l}\text { Goat anti-Rabbit IgG Secondary } \\
\text { Antibody, Alexa Fluor } 647\end{array}$ & Thermo Fisher Scientific & A-21245; RRID:AB_2535813 & $(1: 250)$ \\
\hline Other & $\begin{array}{l}\text { DAPI (4',6-Diamidino-2-Phenylindole, } \\
\text { Dihydrochloride) }\end{array}$ & Thermo Fisher Scientific & D1306; RRID:AB_2629482 & $(0.1 \mu \mathrm{g} / \mu \mathrm{l})$ \\
\hline $\begin{array}{l}\text { Chemical compound, } \\
\text { drug }\end{array}$ & $\begin{array}{l}\text { Dextran, Alexa Fluor }{ }^{\mathrm{TM}} 488 ; 10,000 \mathrm{MW} \text {, } \\
\text { Anionic, Fixable }\end{array}$ & Thermo Fisher Scientific & D22910 & \\
\hline $\begin{array}{l}\text { Chemical compound, } \\
\text { drug }\end{array}$ & $\begin{array}{l}\text { Dextran, Alexa Fluor TM } 555 ; 10,000 \mathrm{MW} \text {, } \\
\text { Anionic, Fixable }\end{array}$ & Thermo Fisher Scientific & D34679 & \\
\hline $\begin{array}{l}\text { Chemical compound, } \\
\text { drug }\end{array}$ & $\begin{array}{l}\text { Dextran, Alexa Fluor }{ }^{\mathrm{TM}} 647 ; 10,000 \mathrm{MW} \text {, } \\
\text { Anionic, Fixable }\end{array}$ & Thermo Fisher Scientific & D22914 & \\
\hline $\begin{array}{l}\text { Chemical compound, } \\
\text { drug }\end{array}$ & $\begin{array}{l}\text { Dextran, Cascade Blue }{ }^{\mathrm{TM}}, 10,000 \mathrm{MW}, \\
\text { Anionic, Lysine Fixable }\end{array}$ & Thermo Fisher Scientific & D1976 & \\
\hline Deposited Data & Mnemiopsis Genome Project & NIH-NHGRI & $\begin{array}{l}\text { https://kona.nhgri.nih.gov/mne } \\
\text { miopsis/ }\end{array}$ & \\
\hline $\begin{array}{l}\text { Sequence-based } \\
\text { reagent }\end{array}$ & $\begin{array}{l}\text { MIß-catenin: F- } \\
\text { ATGGAAACGCCAGTATATCAAGAGC; } \\
\text { R- GATGGCCGCATACCAGTTC }\end{array}$ & & ML073715a & \\
\hline $\begin{array}{l}\text { Sequence-based } \\
\text { reagent }\end{array}$ & $\begin{array}{l}\text { sgRNAs MIß-catenin: 1- } \\
\text { GGCGGGTCTGACGACAGATG; 2- } \\
\text { GGGCGGAGATGTGGTACTCC; 3- } \\
\text { GGGGTGCCTCCGGGCGCCGG }\end{array}$ & $\begin{array}{l}\text { CRISPRevolution sgRNA; } \\
\text { Synthego }\end{array}$ & ML073715a & \\
\hline $\begin{array}{l}\text { Recombinant DNA } \\
\text { reagent }\end{array}$ & Lv-cadherin expression constructs & Wikramanayake et al., 2003 & Recombinant DNA reagent & $\begin{array}{l}\text { Lv-cadherin } \\
\text { expression } \\
\text { constructs }\end{array}$ \\
\hline Software, algorithm & Fiji (ImageJ) & $\mathrm{NIH}$ & http://fiji.sc & \\
\hline
\end{tabular}




\begin{tabular}{|l|l|l|l|l|}
\hline Software, algorithm & Imaris 7.6.4 & Bitplane Inc. & \\
\hline Software, algorithm & CRISPRscan & Moreno-Mateos et al., 2015 & http://www.crisprscan.org/ & \\
\hline
\end{tabular}

